\title{
地下水流速の新しい測定方法の試み*
}

流動電位法

伊藤芳朗 ${ }^{* *}$. 斎藤輝夫 $* *$. 市川 浩 $* *$. 南雲政博 $* *$. 川口英雄 $* *$. 竹内篤雄 $* * *$

\section{Proposal of a New Technique to Detect the Flow Rate of Underground Water from the Variations of Streaming Potential - The Streaming Potential Technique-}

\author{
Yoshiro ITO**, Teruo SAITO**, Ko ICHIKAWA**, Masahiro NAGUMO**, \\ Hideo KAWAGUCHI**, and Atsuo TAKEUCHI ${ }^{* * *}$
}

\begin{abstract}
A new technique is developed to detect the flow rate of underground water. Theoretically, it is based upon some temporal variations of existing stream potential associated with movement of saline solution injected into underground water. In several landslide regions in Japan, experimental measurements are carried out for the variations of streaming potential with the lead electrodes which are arranged in various geometries on the ground surface, after injection of saline solution into shallow underground water.

It is shown that the flow rates detected by the present "Streaming Potential Technique" are in good agreement with those by the conventional tracer technique. The streaming potential technique gains an advantage over the tracer technique in getting possible instantaneous values. Moreover, it is expected to estimate the mass flux of underground water from the variances of streaming potential.
\end{abstract}

I まえがき

地すべり地における地下水の追跡試験では、地す ベり地の頭部のボーリング孔に、色素であるフルオ レッセンソーダか食塩を投入して、地すべり地域内 外のボーリング孔、井戸、涌水、池沼、小川などで トレーサを検出し、それらの位置関係、到達時間か
ら地下水流動経路と流速を決定している。地すべり 地帯における地下水の挙動が、地すべり発生、促進 の主たる誘因とされているので、地下水の流動状態、 供給経路について確実な情報をうることに大きな努 カが払われている。

地すべり地において、問題とする地下水は浅管地 下水(深さ10〜30m)であって、地すべりの安定を図

*1980年度、日本地下水学会秋季講演会において発表した内容に加筆したものである。本研究に要した費用の

一部は、日本私学振興財団の学術研究振與資金によった。

**関東学院大学工学部 Faculty of Engineering, Kanto Gakuin University

***京都大学防災研究所 Disaster Prevention Research Institute, Kyoto University 
る一つの方法として、この地下水の排水工事を行う。 ビこの地点に排水ボーリングを行うかを決定するた めには、精密な地下水分布の調査が要請される。

したがって、一般の沖積平野で実施される地下水 調査よりも測点密度は大きい。地すべり地でのト レーサ法では $30 \sim 50 \mathrm{~m}$ 間隔の測点の密度が望まれ る。しかし経費の点から、既存の地質調查用のボー リング孔、湧水、井戸などが使われるため、測点密 度の偏りが避け難い。

竹内(1983)は、ボーリング孔、湧水などに頼らな い、 $1 \mathrm{~m}$ 深の地温測定によって、浅層地下水の水 流脈を検出する測定法(地温測定による地下水流脈 探査法、以下では地温探査法と略す)を確立し、多 くの探査例によってその有効性を実証してきた。こ の方法により流動している地下水流脈の水温と地温 の温度差の検出によって、地下水流脈の存在、流動 経路、その梁さ、大きさが推定できる。しかも直接 法であるトレーサ法と違って、ボーリング孔、湧水、 井戸などの位置に左右されずに、間接法である地温 探査法では、任意な測線が設定できて、必要に応じ て測定密度をいくらでも高めることができる。

しかし、地温探査法では、地下水流脈の地下水流 速を見積ることは困難である。そこで流速を検出す る方法として、地すべり地などの斜面の頭部のボー リング孔に・食塩水を投入し、それの流下に伴って 発生する流動電位の変化を、地表面にて検出し、そ の時間的空間的変化を測定することにより流速を算 定する方法を武みたので、その予備実験について述 ベることにする。

\section{II＼cjkstart地下水の流動による流動電位の発生}

細管または多孔体の中の.液体の両端に $\Delta \mathrm{p}$ の圧力 差を加えたときに、それらの両端に流動電位差 $\mathrm{E}$ が発生する。このEは、イオン二重層の考えから、 Helmholtz-Smoluchowski によって、次の式で与
えられている(北原ら、1972)。

$$
\mathrm{E}=\frac{\triangle \mathrm{p} \cdot \mathrm{D} \cdot \boldsymbol{\zeta} \cdot \rho}{4 \pi \eta}
$$

ここにD は二重層間の液体の誘電率、 $\rho$ は液体 の比抵抗、らはゼー夕電位、 $\eta$ は液体の粘性係数で ある。

地中の孔隙中を流動する地下水を、多孔体中の液 体の流動として考えると、上式を適用できる。また、 パイプ内の液体の流れが層流の場合には、流動電流 はパイプ径には依存しなくて、平均流速に比例する 理論式、乱流の場合にはパイプ径に依存し、流速の 2 乗に比例する実験式があり(静電気学会, 1981)、 地下水の流動によって、流動電流(電位)が発生して いることが予想できる。

通常の地下水の流動は定常状態にあるので、発生 しているとしても流動電位は一定である。実際の地 表面において、自然電位の分布を測定すると、流動 電位の存在が検出されるはずであるが、地表面は電 極電位、濃淡電位、酸化還元電位、熱電池、地電流 による電位など(通常それらの時間的変化はゆるや かで小さい)が複合していて、それらを分離して測 定することは著しく困難である。したがって、流動 電位のみを検出することは、そのままではできない。 そこで、地下水の流動によって発生する流動電位 の直接の検出として、われわれは、地下水のみ変動 する場合の電位変化の観測を行ってきた。

それは、天然の間欠泉の周期的噴出に伴う流動電 位の発生の測定である(伊藤ら、1978)。噴出高 $30 \mathrm{~cm}$ で、その近傍の地表面における流動電位の発 生は電位傾度として $0.24 \mathrm{mV} / \mathrm{m}$ で、噴出孔から離 れるに従って減衰していることが観測された。これ は、式 $(2 \cdot 1)$ における圧力変化 $\Delta \mathrm{p}$ に比例する流 動電位 Eである。

また、人工的な地下水流動によって発生した流動 電位の場合として、ポンプによって揚湯している温 泉(伊豆烟毛温泉)において、ポンプ停止に上る水位 


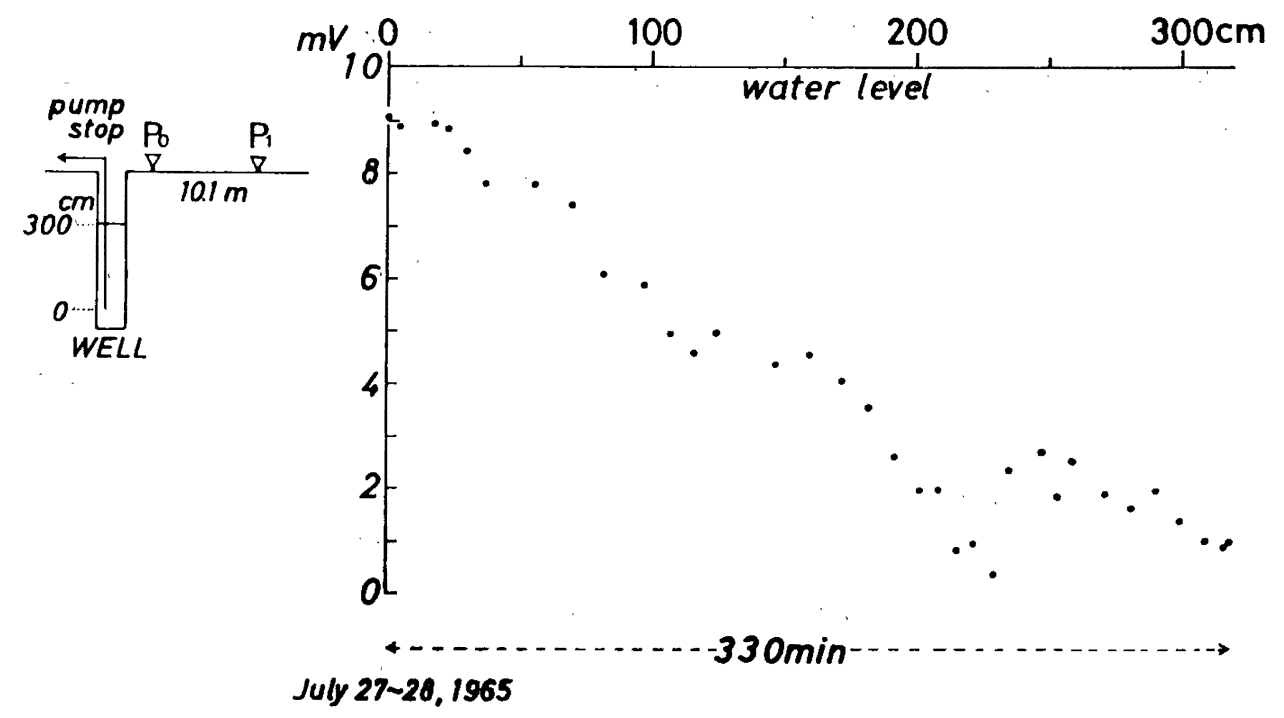

図-1 畑毛温泉源泉井戸における揚水停止による水位回復と地表電位変化との相関

Fig. 1 Relation between the variation of electric potential and the recovering of water level after turning off of discharge in a hot spring well at Hatage.

回復と電位変化の測定の例を図- 1 に示す(伊藤ら、 1973 )。泉温 $35^{\circ} \mathrm{C} 、 41 \Omega \cdot \mathrm{m}$ の単純、弱ア几カリ性 の温泉を毎分 $400 \ell$ 揚湯している源泉の井戸のまわ りで、硫酸銅電極と電位差計によって電位の測定を おこなった結果である。

以上の 2 例にみられるように、地下水の流動に よって流動電位が発生することが直接確認できた。

\section{III 流動電位の変化による地下水流脈の流速の検出}

地すべり地における浅層地下水は、流動によって 流動電位を発生していることは確実であるが、定常 状態であるため式( 2 ・1)の右辺は不変であって、 流動電位 Eは時間とともに変わらない。

そこで、地下氷流脈に食塩水を注入してみる。食 塩水はある拡がり(食塩水塊と名付ける)をもったま ま、地下水の流速にしたがって流動する。食塩を含 む地下水は、含まない地下水に対して、水比抵抗 $\rho$ 、

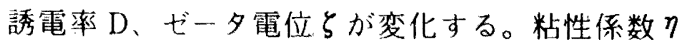

は水温のみに依存し、食塩の混入によっては変化し ないものとすれば、地下水温は短時間では変化しな いので、クは一定と考え、 $\Delta \mathrm{p}$ は不変とみなせるか ら式( $2 \cdot 1$ )の食塩混入による変化は、

$$
\frac{\Delta \mathrm{E}}{\mathrm{E}}=\frac{\Delta \mathrm{D}}{\mathrm{D}}+\frac{\Delta \zeta}{\zeta}+\frac{\Delta \rho}{\rho}
$$

となる。誘電率 D、比抵抗 $\rho$ は、食塩混入の地下 水では、真水より電解質になるので、いずれも低下 するものと考えることができる。ゼ一夕電位らは、 Modi et al. (1957)の実験より、食塩濃度の増加と ともに低下する $(\mathrm{pH}$ が大きい場合は逆となる)こと がわかる。また、食塩濃度が薄い範囲内で、濃度増 加に従つて、流動電位 E が減少するとすれば(遠藤 ら、1959)、食塩濃度も考慮しておく必要がある。

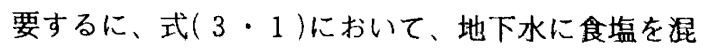
入すれば、多くの場合発生している流動電位 Eは、

$$
\frac{\triangle E}{E}<0
$$

となって娍少する(地下水はほぼ中性であるので、 
$\mathrm{pH}$ の大きい場合は除く)。地表面における他の自 然電位は、短時間では変化しない(地電流も磁気嵐 のとき以外は変化は小さい)から、地表面における 電位変化は、食塩水を含む地下水の流動によってひ きおこされたもののみとなる。

地下水の流動は、ダルシーの法則に従っているも のとすると、その動水勾配と式（2・1）の圧力差 $\Delta \mathrm{p}$ とは同じ意味であるから、地下水流脈の存在する ところには、流動電位が絶えず発生している。

しかし、地下水流脈の上流点に食塩水を投入する と、食塩水塊となって流下し、それまでに発生して いた流動電位を、式( $3 \cdot 2)$ によって減少させるの で、地表面の電位分布が変化し、食塩水塊の通過と ともに、もとの電位分布に戻る変化が起こることに なる。

そこで、地下水流脈上(と思われる地点)に電極を 多数配置し、ある時刻に上流点に食塩水を注入し、 注入点よりある距離に設置された電極に、電位変化 が起こるまでの経過時間を知れば、地下水流速を算 出できることになる。多数の電極を配置すれば、各 地点におけるそれぞれの流速(ベクトルとしての)を 知ることができる。そこでこの方法を、流動電位法 による地下水流速測定と仮称する。

上述のことを図一 2 に示した。地下水流脈が一層 で、定常流れの場合について考える。眓の左から食 塩水塊 $(\mathrm{NaCl})$ が移動してきて、その前面が、地表 面の $\mathrm{P}$ 点の近くに到達すると、 $\mathrm{P}$ 点の電位は流動 電位変化の曲線 $(\mathrm{mV})$ の L 部のような変化が起こり 始める(図の上部に示した曲線、時間軸の方向は矢 印で示してある)。L 部の変化の開始時の遅速と変 化率の大小は、流速、食塩水の濃度、食塩水塊の大 きさ、地下水面までの深さ、土壌の電気的性質など に関係する。食塩水塊の背面が通過するときは、L 部の変化の向きと逆の電位変化が起こる。図の曲線 の凸部が、それにあたる。そして、食塩水塊の最高 濃度部(ほぼ中心部)が、 $\mathrm{P}$ 点の直下を通過するとき、

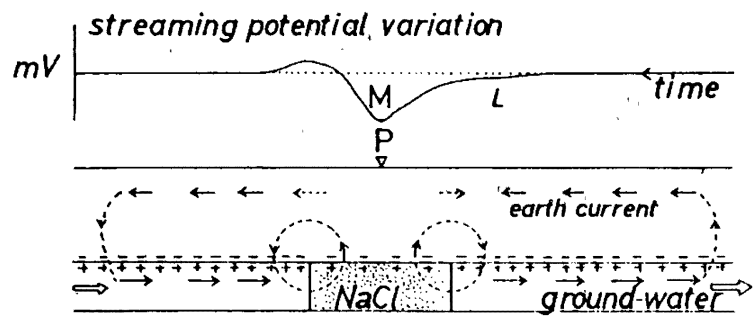

図-2 食塩水の地下流動によって起こる流動電位の時間 的変化のモデル

Fig. 2 A time depending model of steaming potential caused by the underground movement of saline solution.

図の極小值 $M$ をもつ変化が起こる。

図- 2 の $\mathrm{P}$ 点を、地下水流脈上の各点と考えると、 食塩水投入地点の近くの電位変化は早くから始ま り、遠くの電位変化は遅れる。食塩水塊は流下に従っ て、拡散、吸着のため食塩水の濃度が低下するので、 電位変化の大きさは小さく、時間的変化率(見かけ の変化の鋭さ)は小さくなる。地下水流速の測定に は、食塩水塊の中心が通過するときに見られる図2 の流動電位変化曲線の極值 $M$ 点の、各測定点に おける時刻の差より行う。

\section{IV水路における流動電位法の予備実験}

食塩水の地下水への混入による地下水流速測定に 流動電位法を適用するにあたって、水の流動が直接 観察できる水路において予備実験を行った。

1.コンクリート水路における㬰験

開水路は人家の少ない山の中の銭川温泉(秋田県 八幡平)付近の斜面を流下するものを選んだ。開水 路は勾配約 5 、幅 $30 \mathrm{~cm}$ 、深さ $70 \mathrm{~cm}$ のコンクリー トU 字溝であり、水路の流水は深さ $1.5 \mathrm{~cm}$ 、水温 $20^{\circ} \mathrm{C}$ (気温 $\left.23^{\circ} \mathrm{C}\right) 、 \mathrm{pH} 8.1$ 、水比抵抗 $70 \Omega \cdot \mathrm{m}$ 、流量 $5.5 \ell / \mathrm{sec}$ であった。電極は鉛管で、口径 $5 \mathrm{~cm}$ 、 長さ $5 \mathrm{~cm}$ のものを使用し、その開水路における食 塩水投入点、電極配置なよ゙を図一 3 に示した。

図- 4 は図- 3 のS 点に食塩水(水 $1 \ell$ 、食塩 $9.4 \mathrm{~g}$ ) 
を投入し、 $\mathrm{E}_{0}$ をを共通電極(正極)とし、 $\mathrm{E}_{0}-\mathrm{E}_{2} 、 \mathrm{E}_{0}$ - $E_{1}$ 電極での電位変化の記録である。記録計はぺ ンレコーダを用い、大きな固有地表電位差(時間的 変化のない部分)を打消して、感度を適当にあげて 使用した。以下同椂にして、同じ記録計を使った。 $\mathrm{E}_{0}-\mathrm{E}_{2}$ の固有電位差は(ー) $16 \mathrm{mV}$ であった。この 電位は、主として斜面に沿って生じている流動電位 と思われる。

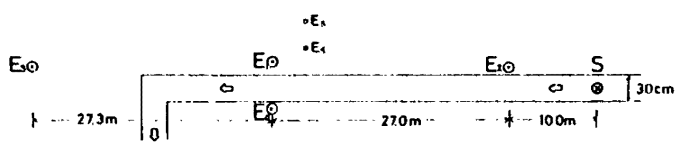

図-3食塩水を流下させたコンクリート開水路と電極配 in

Fig. 3 An open concrete channel, through which saline solution passes, and the locations of electrodes.

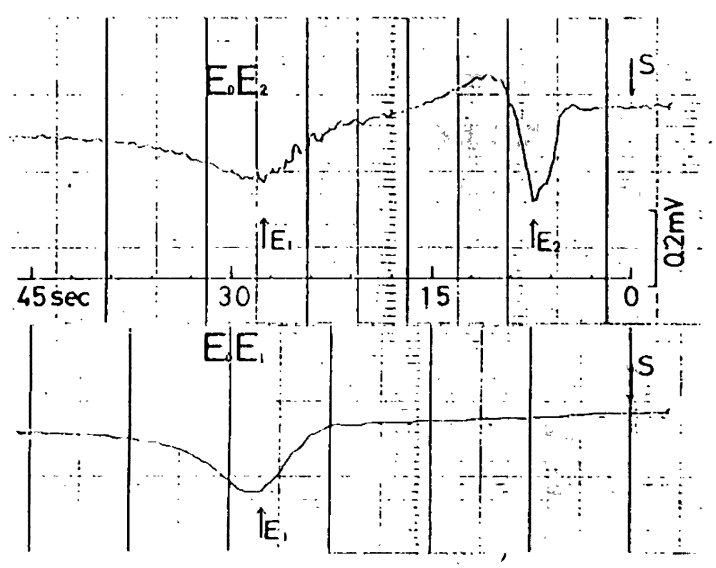

図- 4 開水路における食塩水流下による流動電位

Fig. 4 Streaming potential caused by movement of the saline solution in an open channel.

図ー 4 の $\mathrm{E}_{0}-\mathrm{E}_{2}$ の変化をみると、食塩水の投入 後7. $1 \mathrm{sec}$ 後と $27.8 \mathrm{sec}$ 後に、それぞれ極值があらわ れ(図の $E_{2}$ 亡 $E_{1}$ )、それらはそれぞれ投入時電位に 対して、0.24mV、0.18mV の低下である。電位の 極值(この場合は極小值)の時間は、食塩水塊の電極
点の通過時刻であるから、図-4の $E_{0}-E_{2}$ の記録 より、 $\mathrm{S}$ 点より $\mathrm{E}_{2}$ 点までの流速は、1.41m/sec、 $\mathrm{E}_{1}$ 点までの流速は、1. $33 \mathrm{~m} / \mathrm{sec}$ 算出できる。ま た、 $\mathrm{E}_{2}$ 点と $\mathrm{E}_{1}$ 点の間の流速は $1.30 \mathrm{~m} / \mathrm{sec}$ となる。 また、電導度計による $\mathrm{S}$ 点と $\mathrm{E}_{1}$ 点までの流速は 4 回平均で $1.35 \mathrm{~m} / \mathrm{sec}$ であった。

図-4における $E_{0}-E_{2}$ の第 2 の極小值 $\left(E_{1}\right)$ の時 間に、 $E_{0}-E_{1} に も$ 同時間に同様な変化 $\left(E_{1}\right)$ が起こっ ている。それは食塩水塊の $\mathrm{E}_{0}$ 点を通過した時であ る。また、 $\mathrm{E}_{2}$ 点より $\mathrm{E}_{0}$ 点における電位変化は小さ く、変化の形も鋭くないのは、食塩水塊のひろがり が大きくなり、塩分がうすくなったものと考えられ る。そのひろがりの原因は流速が $1.35 \mathrm{~m} / \mathrm{sec}$ と大 きいことと、水路の河床の凹凸によるものと思われ る。

図- 5 は、 $E_{3}$ 電極を水路より遠くへ離して共通基 準電極として、 $E_{3}-E_{1} 、 E_{3}-E_{2}$ 電極の電位差を(図 - 3 参照)、 $\mathrm{S}$ 点に食塩水塊 (食塩 $5.5 \mathrm{~g}$ 、水 $1 \ell$ )を投 入して記録したものである。S 点に食塩水投入後、 $E_{2}$ 点では7. $1 \mathrm{sec}$ 後に、 $E_{1}$ 点では $30.9 \mathrm{sec}$ 後に、電 位変化の極小值があらわれ、流速はそれぞれ $1.40 \mathrm{~m}$ $/ \mathrm{sec}$ と $1.20 \mathrm{~m} / \mathrm{sec}$ となる。流路が $37 \mathrm{~m}$ と長くな ると、流速の算出において数\%の差が生じる。それ は、開水路の流速が、水路の抵抗と勾配の変化によっ て一様でないことによる。

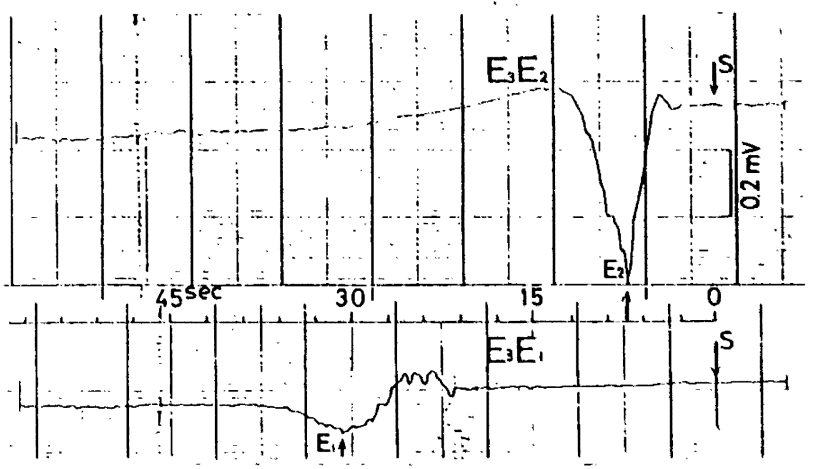

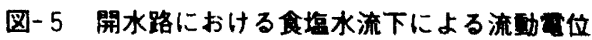

Fig. 5 Streaming potential caused by movement of the saline solution in an open channel. 
水路と直角方向の、距離に対する電位変化の減衰 の程度をみる奉験も行った。水路より $1.6 \mathrm{~m}$ の点 $\left(\mathrm{E}_{4}\right)$ では $6 \%$ に、 $4.6 \mathrm{~m}$ の点 $\left(\mathrm{E}_{3}\right)$ では.2\%位に距離 に対して大きく減衰する。 $\mathrm{E}_{0}$ と $\mathrm{E}_{2}$ の電極は水路よ ク0.15m に埋設したが、 $E_{1}$ の電極は $0.7 \mathrm{~m}$ に埋設さ れている。もし $E_{0}$ と $E_{1}$ の電極が水路に対して等間 隔であれば、図-4の $E_{0}-E_{1}$ の電位変化は現れな いはずであるが、非対称のために現れたものと考え られる。また、投入水の塩分濃度を変えた実験も行っ た。結果を図ー6に示した。塩分浱度に比例した電 位変化の発生が見られることがわかる。また、水路 の流水は pH8.1であるので、ホウ酸や重曹(重炭酸 ソーダ)もトレーサとして投入してみた。水 $1 \ell$ に ホウ酸 $9 \mathrm{~g} 、 27 \mathrm{~g} 、 50 \mathrm{~g}$ を溶かした液を投入した場合 の $\mathrm{E}_{3}-\mathrm{E}_{2}$ 電極の $\mathrm{E}_{2}$ 点(図- 3 参照)における電位低 下の変化は、それぞれ $0.019 \mathrm{mV} 、 0.020 \mathrm{mV} 、 0$. $040 \mathrm{mV}$ であった。重曹は粉末の直接投入で、10g、 $50 \mathrm{~g} 、 150 \mathrm{~g}$ の場合について、電位低下は、それぞれ $0.17 \mathrm{mV} 、 0.39 \mathrm{mV} 、 0.53 \mathrm{mV}$ であった。

以上の開水路における実験の結果と問題点をまと めてみると次のようになる。

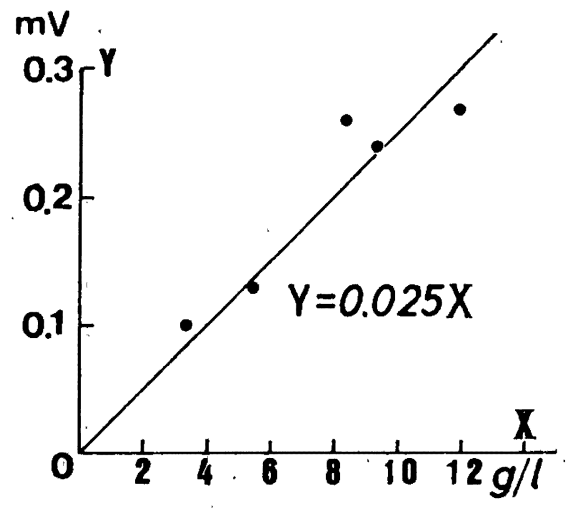

图-6 食㙁水㵂度と流的里位の大きさとの関係

Fig. 6 Relation between concentration of saline solution and magnitude of streaming potential.
1）投入食塩水は、水塊をなして流下するが、そ の水塊は長さを増し(川幅に変化がないので、体積 の変化は主として長さの変化のみによる)、塩分濃 度は低下し、発生する電位変化はゆるやかとなり、 かつ小さくなる。

2 ）投入食塩水塊に上る電位変化より求めた流速 と、電導度計による水比抵抗の変化より求めた流速 とはよく一致する。ただし、電導計による流速は、 電導度の最大值に達する時間で求めなければならな い。

3 ）発生する電位変化は、水路より遠ざかるに 従って急速に減衰する。水路より直角に $4.6 \mathrm{~m}$ 離れ ると $2 \%$ に減少するのが見られた。

4 ) 発生する電位変化の大きさは、投入塩分濃度 に比例する(図- 6 )。

5 ) 流水は $\mathrm{pH} 8.1$ 、比抵抗 $70 \Omega \cdot \mathrm{m}$ であるが、 投入する食塩 $9.4 \mathrm{~g}$ 、ホウ酸 $9 \mathrm{~g}$ 、重曹 $10 \mathrm{~g}$ に対して、 電位変化の大きさは、それぞれ0. $24 \mathrm{mV} 、 0.019 \mathrm{mV}$ 、 $0.17 \mathrm{mV}$ であり、その割合は $13 ： 1 ： 8.5$ であり、 同重量では食塩による電位変化が最大である。この ことは、トレーサは $\mathrm{pH}$ 変化させるものを用いるよ りも、比抵抗変化させるものの方が流水の流動電位 を変化させる効果が大きいということが考えられ る。

\section{2. 渓流における実験}

自然の渓流における流動電位法の実験として、新 潟県北魚沼郡入広瀬村の大白川新田の破間川に注 ぐ小さな渓流を選んだ。やや急な斜面に涌泉があり、 そこからやや蛇行して斜面を川幅 $30 － 50 \mathrm{~cm}$ 、深さ $5 〜 2 \mathrm{~cm}$ の川をなして流れている。斜面は䃯まじ りの赤土であり、かなり透水性がよい。涌水は巨石 の下から出ていて、実験日の水温は $8.2^{\circ} \mathrm{C}$ 、湧出量 $2.6 \ell / \mathrm{sec}$ 、水比抵抗 $450 \Omega \cdot \mathrm{m}$ 、中性であった。 電極配置は図一 7 に示してあり、湧泉の出口の水溜 り(約 $\left.0.5 \mathrm{~m}^{2}\right)$ に投入した食塩水 $(300 \mathrm{~g} / 5 \ell)$ の流下 に伴った電位変化の記録を図ー8に示した。 $\mathrm{O}_{1} \mathrm{E}_{1}$ 電 


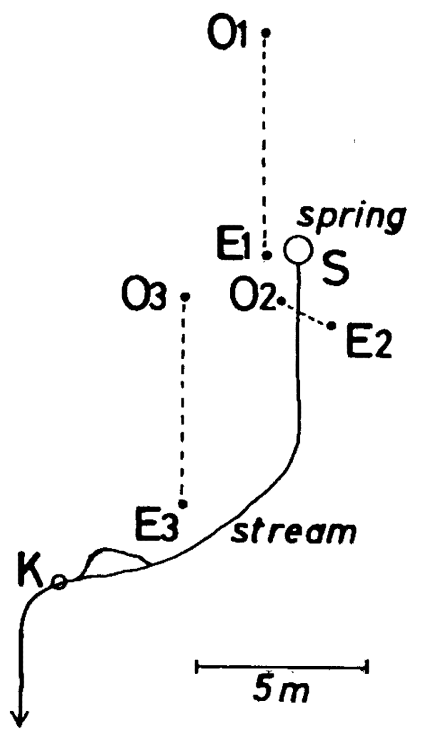

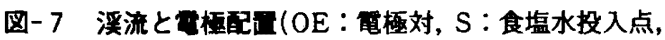
$\mathrm{K}$ ：水の電筫度㨽定点）

Fig. 7 Location of a pair of electrodes relative with a mountain stream.
極( 0 は基準電極、以下同じ)による電位は、食塩 水投入と同時に正方向に変化、つまり、 $E_{1}$ 電極に 負の電荷が与えられたことになる。投入(S)上り電 位極大值 $(0.65 \mathrm{mV})$ に達する2.3 $3 \mathrm{sec}$ は、食塩水の投 入時間であり、続く $15 \mathrm{sec}$ のゆるやかな電位の减衰 は、水溜りより食塩水の流出が終了するに必要な時 間である。したがって、食塩水塊は流下するにつれ て、かなり長いものになる。その上、この小川の河 床は碰が多いので、1.のコンクリート水路よりも 複雑な食塩水塊となる。

$\mathrm{O}_{2} \mathrm{E}_{2}$ 電極による変化は、 $\mathrm{O}_{2}$ 電極の方が $\mathrm{E}_{2}$ 電極よ り $0.7 \mathrm{~m}$ 上流に位置するため、 $\mathrm{O}_{2}$ 電極に負の電荷が 与えられ電位が極小値 $(0.5 \mathrm{mV})$ に向うが、 $\mathrm{O}_{2} \mathrm{E}_{2}$ 電 極間隔が $2 \mathrm{~m}$ と短いため、 $\mathrm{E}_{2}$ 電極にも負の電荷の 影響を与えながら電位変化する。S 点に食塩水投入 後、電位の極小值に達する時間は19.5secであり、
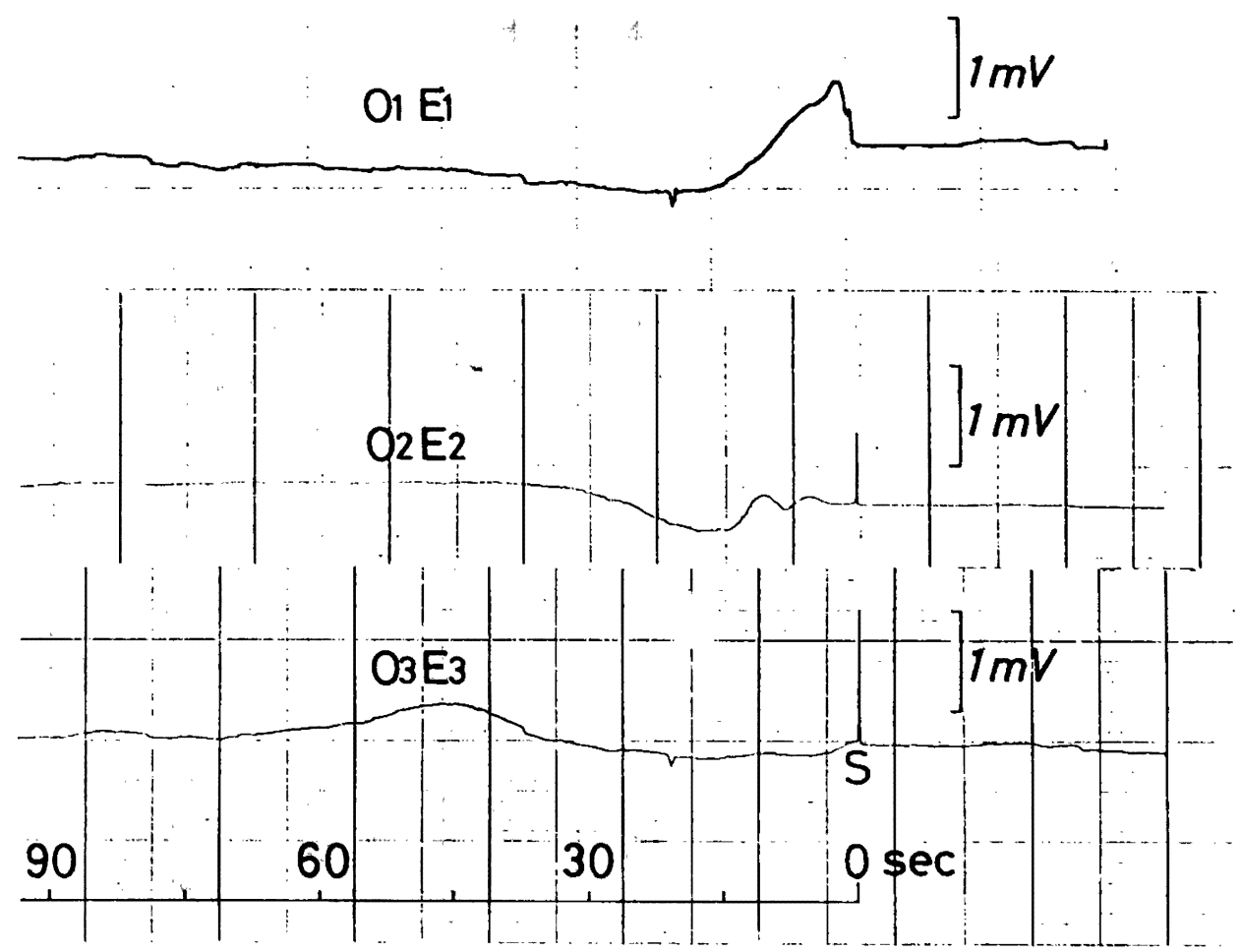

図-8 渓流における食塩水流下による流呩要位

Fig. 8 Streaming potential caused by movement of the saline solution in a moutain stream. 
$\mathrm{S}$ 点と $\mathrm{O}_{2}$ 点の距離は $2.4 \mathrm{~m}$ であるので $0.12 \mathrm{~m} / \mathrm{sec}$ の流速である。

$\mathrm{O}_{3} \mathrm{E}_{3}$ 電極による変化は、 $\mathrm{E}_{3}$ 電極に負の電荷が与 えられ、0.4mV の極大值に、S 点に食塩水が投入 されてから51sec 後に達している。渓流は $\mathrm{E}_{3}$ 点近 くまでは蛇行し、その勾配をさまざまに変えて、 $\mathrm{E}_{3}$ 点付近ではゆるやかとなている。 $\mathrm{S}$ 点から $\mathrm{E}_{3}$ 点までの川の長さは8. 4m であるから、流速は0. $16 \mathrm{~m} / \mathrm{sec}$ となる。また、 $\mathrm{O}_{2}$ 点と $\mathrm{E}_{3}$ 点までの川の 長さ $6.0 \mathrm{~m}$ に対しては、 $31.5 \mathrm{sec}$ の経過時間となり、 その大半が急勾配であるこの付近の流速ば $0.19 \mathrm{~m} /$ secとなる。

以上をまとめてみると、この渓流の流速は、湧泉 のS 点より $\mathrm{O}_{2}$ 点、 $2.4 \mathrm{~m}$ までは $0.12 \mathrm{~m} / \mathrm{sec}$ であり、 それよりさらに $6.0 \mathrm{~m} の \mathrm{E}_{3}$ 点の間は0: $19 \mathrm{~m} / \mathrm{sec}$ で あり、 $\mathrm{S}$ 点より $\mathrm{E}_{3}$ 点までの $8.4 \mathrm{~m}$ の平均流速は 0. $16 \mathrm{~m} / \mathrm{sec}$ となる。

一方、 $\mathrm{S}$ 点に食塩水を投入した後の電導度計によ る12. $5 \mathrm{~m}$ 地点の $\mathrm{K}$ 点(図-7参照)における記録を図 - 9 に示す。極大值が $2 つ$ るのは、図-7において $E_{3}$ 点を通過した流れが斜面の中腹のやや平坦な場 所において分岐し、その上、水溜りをつくっている ことによると思われる。 $\mathrm{S}-\mathrm{C}_{1}$ の時間は78sec であ り、 $\mathrm{S}$ 点より $12.5 \mathrm{~m}$ 下流の $\mathrm{K}$ 点までの流速は 0. $16 \mathrm{~m} / \mathrm{sec}$ となる。 $\mathrm{C}_{2}$ は川の分流が合流した後の食
塩水の濃度増大による変化である。

さらに図-9は、流下する食塩水塊の大きさを示 している。流速の大きいこの渓流では、食塩水塊は $20 \mathrm{~m}$ 程度の、大きさとなる。このことが、図- 8 の電 位変化の回復の遅れ、極值が鋭く出ない原因である。 また、図- 9 における塩分濃度の 2 つ以上の極大 值を有する変化と同様なことは、地下水流脈の流下 に伴う分流や合流によっても生じることが充分考え られるので、流動電位法による地下水流速(場所、 大きさ、向き測定の解析に゙あたっては留意すべき 問題である。

溪流における流動電位法の実験より得られた結果 をまとめてみると次のようになる。

1 ）渓流を流下する食塩水塊によって生じる土地 の電荷は負であり、流下の距離によって変化する電 位の大きさは、図-10に示すように: 指数曲線的に 減衰する。自然水路では、トレーサの食塩水の吸着、 水塊の拡大による濃度の減少が同じような指数曲線 的な変化をすることを図は示すものといえる。流下 するに従って、食塩水塊が急速に消滅してしまうこ とがないことは、流動電位法による流速測定の適用 の地理的範囲の拡大につながる有利な傾向である。

2 ) 溪流を挾む対の電極配置による電位変化の測 定では、電位変化が複雑となる。これより流速を算 出することは困難であるが、地下水の場合には、電

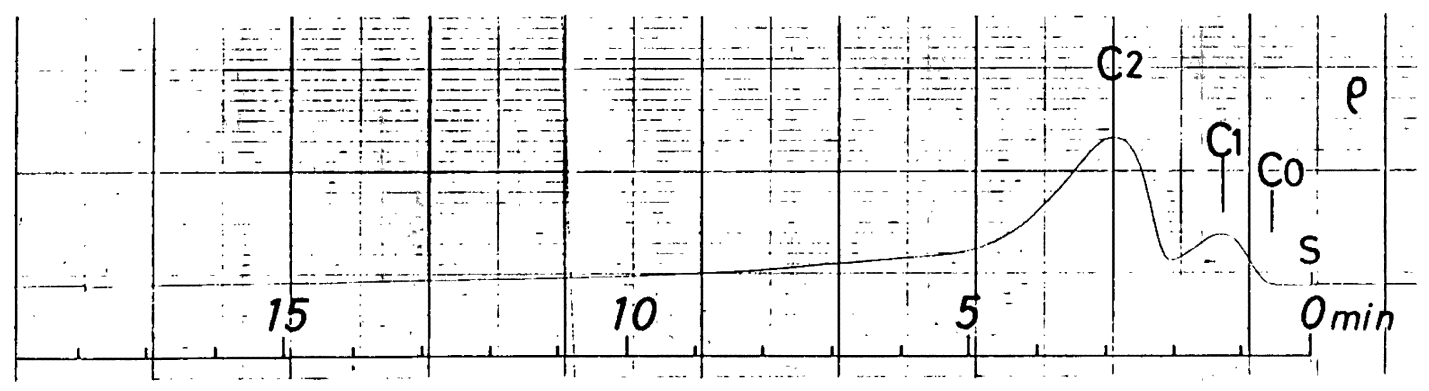

図-9 溪流における食塩水流下による電学度 $(\rho)$ 変化

Fig. 9 A variation of the electric conductivity caused by movement of the saline solution in a mountain stream. 


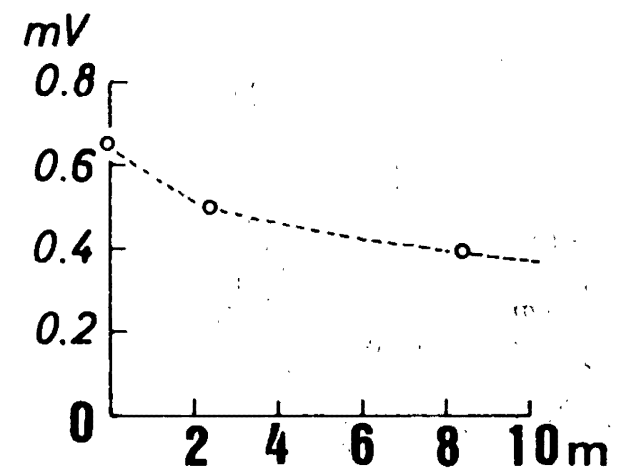

図-10 渓流における流下食塩水の希积に伴う流動電位の 減衰

Fig. 10 Decaying stream potential associated with dilution of flowing saline solution in a mountain stream.

位変化の複雑さかららその水流脈の存在位置の判定に 利用できるであろう。

3 ）複雑な電位変化がみられる他の場合として、 食塩水の投入が短時間で、単純である場合、下流に おける電位変化の極值が短時間のうちに複数あらわ れるときは、地下水に適用してみると、地下水流脈 の分流による可能性が考えられる。

3. 埋設排水管による実験
これまでの１，，2．の野外実験は、いずれも地 表水の流動に边る流動電位の電位変化を見たもので ある。地下において変化する電荷による地表の電位 変化を見るために、地下に埋設された、流動水のあ るパイプを利用する実験を試みた。

地すべり地帯では、地下水排除のために、数多く のボーリング孔からの地下水を井戸に集め、そこか 放本のパイプをもって地すべり地帯外の流路に排 水している。実験は、この排水パイプが埋設されて 以て、排水が自然流下している場所を選んだ。

図-11に、兵庫県美方郡美方町の石寺地すべり地 の集水井と排水管ならびに電極配置を示してある。 測定時の地乤水の排水量 (湧出量)は、 $54.5 \ell / \mathrm{min}$ 、 水温 $11.0^{\circ} \mathrm{C} 、 \mathrm{pH} 6 \sim 5$ 、水比抵抗 $170 \Omega \cdot \mathrm{m}$ 、気温 14. $0^{\circ} \mathrm{C}($ 快晴 $)$ であうた。図一-11(b)に見られるよう に、 $87 \mathrm{~m}$ の鉄パイプ(直径 $10 \mathrm{~cm}$ )が、集水井付近て $14 \mathrm{~m}$ の表土、末端の排水溝近くでは $1 \mathrm{~m}$ の表土の

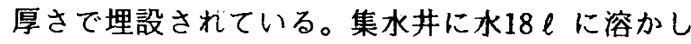
た $5 \mathrm{~kg}$ の食塩を投入し、流下させたときの地表面 電位の変化の記録の一部を図-12に示す。

図-12には、パイプの排水末端部(図-11(b)のP

ISHIDERA<smiles>[2H][13Co][18O]</smiles>

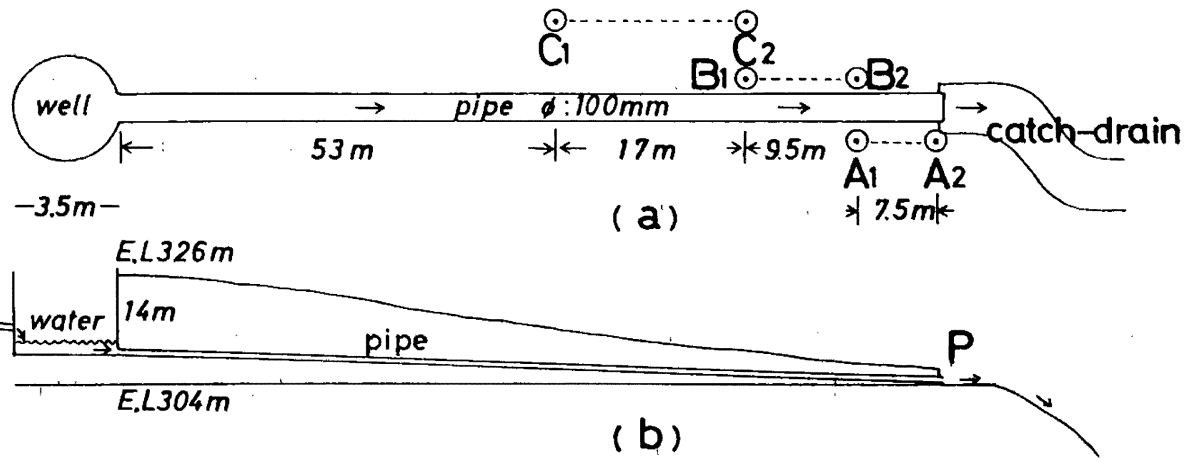

図-11 石寺地すべり地における地下水排水バイブと地表電極配置 ( (a): 平面図, (b): 断面)

Fig. 11 Locations of the electrodes relative to the drainpipe of underground water at Ishidera landslide area. (a): plan and (b): cross section. 


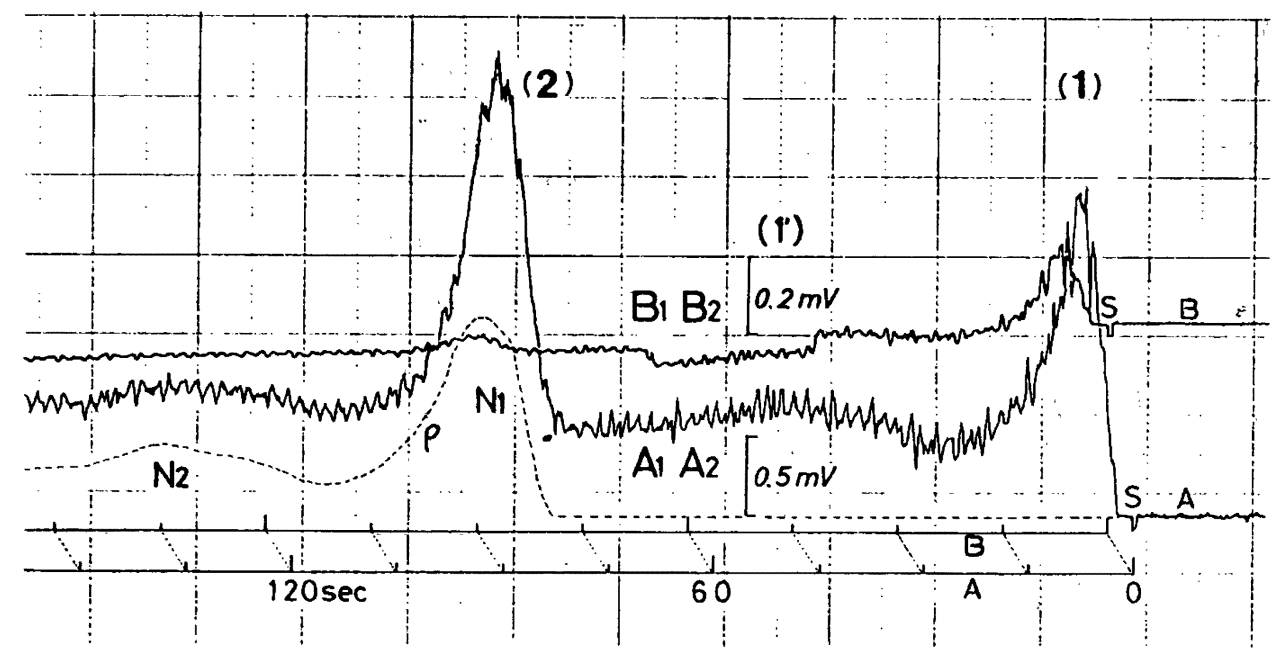

图-12 排水パイブ(鉄)を流下する食㘿水による地表電位变化 $(1)$ と流動電位 $(2)(\mathrm{p}$ ：食塩水の電導度の変化)

Fig. 12 Temporal variation of (1) ground surface-electric potential and (2) streaming potential caused by movement of saline solution through a steel drainpipe. ( $\rho$ indicates variation of electric conductivity of saline solution)

点)における電導度計の記録を $\rho$ 曲線として示して ある。集水井に食塩水投入 $(\mathrm{S})$ 後 $90 \mathrm{sec} に て \rho$ の第 1 波 $\mathrm{N}_{1}$ が排水管末端部に到着し、第 2 波 $\mathrm{N}_{2}$ は第 1

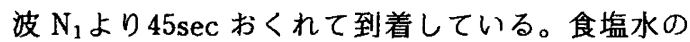
水塊が 2 個生じたのは集水井内の水の動きによるも のであろう。第 1 波 $\mathrm{N}_{1}$ 食塩水塊が、集水井より排 水パイプに流入するや否や、 $\mathrm{A}$ と B 電極の電位は、 図-12にみられるように、上流が正となる向きに、 それぞれ $2.1 \mathrm{mV} 、 0.2 \mathrm{mV}$ の極大値(同図の $(1))$ に 達し、ただちに減少する。そして $45 \mathrm{sec}$ 後に、食塩 水塊第 2 波 $\mathrm{N}_{2}$ に対応する電位変化 (図-12の ( $\left.1^{\prime}{ }^{\prime}\right)$ ) が現れた。

この実験においては、集水井内に投入された食塩 水塊が、排水パイプに流入すると、このパイプ埋設 地域の地表面全体の電位が、同時に変化する(図-11 の $\mathrm{A} 、 \mathrm{~B}$ 電極のみならず、 $\mathrm{C} 、 \mathrm{D}$ 電極の電位も)。 このことは、食塩水が地中の鉄パイプを流動すると きの電位の変化は、直ちに鉄パイプ全体に伝導する ことを示している。また、図-12の（1）の電位の減 衰は、 $\rho$ 曲線の食塩水濃度の減衰より大きい。これ
は、電荷の漏えい(緩和時間)によるものと考えられ る。この問題は、後の図-18においても考察する。

図-12の電位変化の $(2)$ は、 $\rho$ 曲線の第 1 波 $N_{1}$ と 同時刻である。 $\mathrm{A} 、 \mathrm{~B}$ 電極は排水パイプの排出口付 近に配置されていて(図-11)、食塩水塊 $\mathrm{N}_{1}$ が排出口 からコンクリートのU 字溝(幅 $24 \mathrm{~cm}$ 、急傾斜)へ注 がれて流下したとき、U字溝の流動電位が増大し た結果である。なぜならば、食塩水塊 $\mathrm{N}_{1}$ は排水パ イプを通過して排出されてしまっているからであ る。

次にU 字溝を利用して図-13の実験を行った。図 の（1）の電位低下 $0.7 \mathrm{mV}$ は、パイプの排出口を布 でせき止めたときの変化であり、排水の流動によっ てそれまでU 字排水溝に発生していた流動電位の 大きさに相当する。図の $(3)$ は、パイプ中に溜めた 水を、一気に流したときの発生流動電位である。図 の（２）は、パイプからの流水をバケツに集め、排水 溝に流させなかったときの電位変化で、 $(2)$ と同様 であるが、バケツの水を溝に再び流さなかったため、 （３）に相当する電位変化はあらわれない。U字溝 
の流水は、1. $3 \mathrm{~m} / \mathrm{sec}$ の流速、 $0.9 \ell / \mathrm{sec}$ の流量 であり、それによって $0.7 \mathrm{mV}$ (電極間隔 $7.5 \mathrm{~m}$ にお ける)の流動電位が発生していたことがわかった。

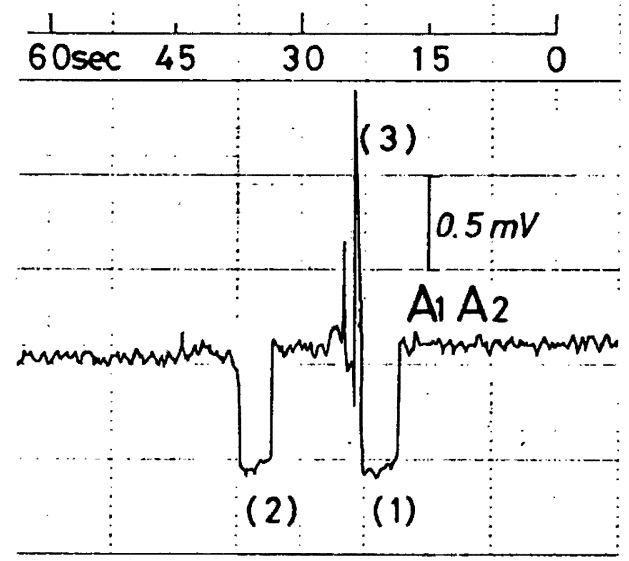

図-13 排水清に発生している流動電位 (1)、（2)と流 增大による流暂電位 ( 3 )

Fig. 13 (1) and (2) show the streaming potential caused by stand still water in a drainage ditch, and (3) shows increase of streaming potential with increase of flow rate.

図-14は、食塩水投入前の地表自然電位(SP)によ る電場の斜面方向の成分の分布である。図に点線で 示した帯は、竹内(1983)による地温探査によって推 定された地下水流脈である。図の SP の傾向が、“斜 面の上部へ向う電流によるものと考えると、地下水 による流動電流とともに、鉄パイプを流れる地下水 も、見掛け上は正電荷を流下させていると考えるこ とができる。

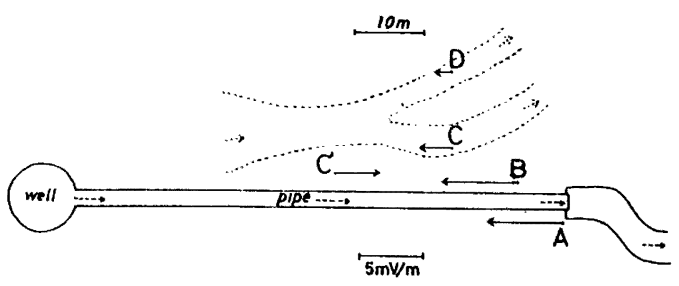

図-14自然電位による電場

Fig. 14 An electric field associated with selfpotential.
図-15は、数回の食塭水の流下実験による A、B、 C、D の電極(図-11)に現れた電位変化の向きょり、 電場を作成したものである。集水井より鉄パイプに 食塩水が流入すると、各点同時に電位変化が起こり、 図のような電場をつくり、約20sec(図-12参照)で娍 衰する。

排水バイプについての同様な実験を、兵庫県美方 郡村岡町の宮神地すべり地においても実施した。集 水井と埋設排水パイプの位置を図-16に示した。排 水の流量は $367 \ell / \mathrm{min}$ 、水温 $10.0^{\circ} \mathrm{C}\left(\right.$ 気温 $\left.14.2^{\circ} \mathrm{C}\right)$ 、 水比抵抗 $5,400 \Omega \cdot m 、 p H 6 \sim 7$ であった。

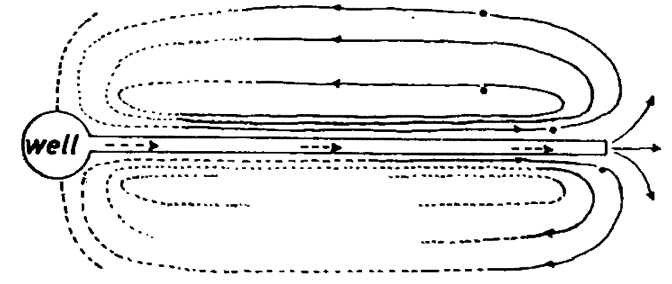

図-15 排水管(鉄)を流下する食塩水による西場

Fig. 15 An electric field caused by movement of "saline solution in a steel drainpipe.

\section{MIYAGAMI}

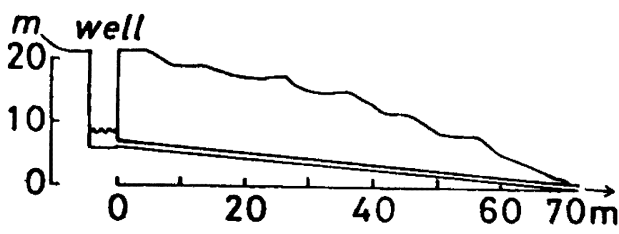

(a)

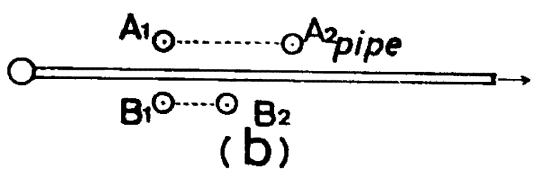

図-16 宮神地すべり地における地下水排水パイブと地表

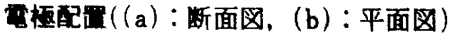

Fig. 16 Location of the ground surface-electrodes relative with a drainpipe of underground water at Miyagami landslide area. (a): cross section and (b): plan. 

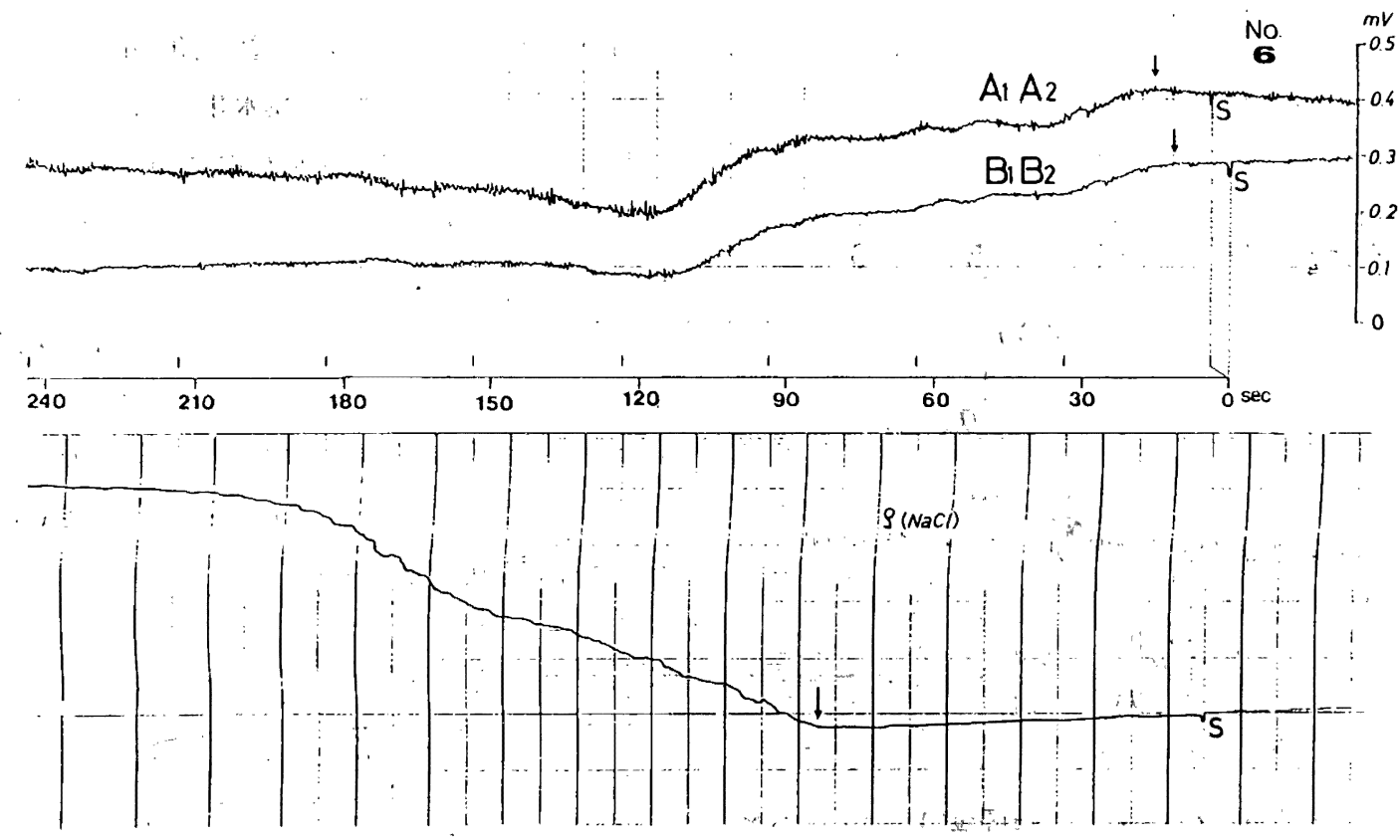

図-17. 排水パイブ(鉄)を流下する食塩水による地表奄位変化と電算度变化 $(\boldsymbol{\rho})$ ，，

Fig. 17 Temporal variations of the ground surface-electric potential and the electric conductivity caused by movement of saline solution through a steel drainpipe.

図-17は、食塩 $2.5 \mathrm{~kg}$ を水 $20 \ell$ に溶かして投入し たときの電位変化(電極配置は図-16)の記録である。 同図の $\rho(\mathrm{NaCl})$ 曲線は、排水パイプの排出口にお ける電導度計による食塩水濃度の変化(時間軸は電 位変化とそろえてある)の記録である。パイプ内の 排水の流速は $0.92 \mathrm{~m} / \mathrm{sec}$ である。食塩水は $\rho$ 曲線 に見られるように $150 \mathrm{sec}$ 以上にわたって集水井よ り流出続けるが、電位変化は $120 \mathrm{sec}$ 後には回復し 始めている。そこで、食塩水濃度 $\rho$ と電位変化を重 ねてみたのが図-18である。

図-18において、(1)と(2)の部分における $\rho$ の急激 な上昇に応じて、 $\mathrm{E} も$ 急激に上昇するが、のの変 化率が小さくなると、 $\mathrm{E}$ は下降しはじめる。この もれ電流が大きいこと(楥和時間が短い)は、集水井 内の食塩水と鉄パイプおよびパイプ内の食塩水(い すれも電尊度が非常に大きい)、士壤からなる回路 の構成から理解できる。

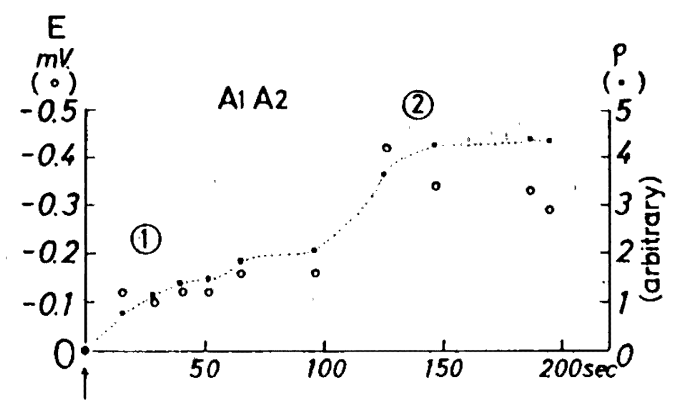

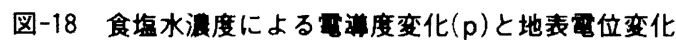
(E)の関係 (1), (2)：p と $\mathrm{E}$ との変化のくいちが ()

Fig. 18 Relation between the variation of electric conductivity $(\rho)$ and the variation of electric potential (E) at the ground surface caused by various concentration of saline solution.

また、図-12、図-17にそれぞれ3.1 sec、0.65 sec の周期をもった電位微動が見られる。それらの原因 について考えてみた。それらの継続時間が10 min以 
上もあることから、食塩水投入の衝撃による集水井 水面の自由振動ではなくて、集水井内に流入する数 本のボーリング孔よりの地下水による残留食塩水の 擾乱によって維持されている周期運動と考えること が妥当のようである。

図-19に、実験に先立って測定され自然電位 (SP) の分布を示す。排水パイプに沿った付近の地表は、 パイプの流水の流れの方向と逆の電場が、その両側 では流れの方向の電場が推定できる。食塩水の流動 によっておこる電位変化から、電場を作成すると図 ー20となる。これは、図-15と同様な電場が考えられ る。

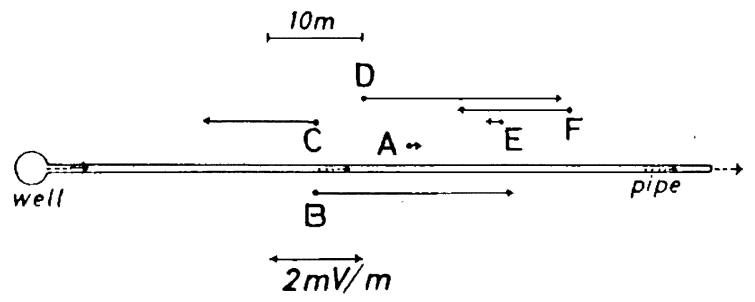

図-19 自然電位による電場

Fig. 19 An electric field associated with selfpotential.

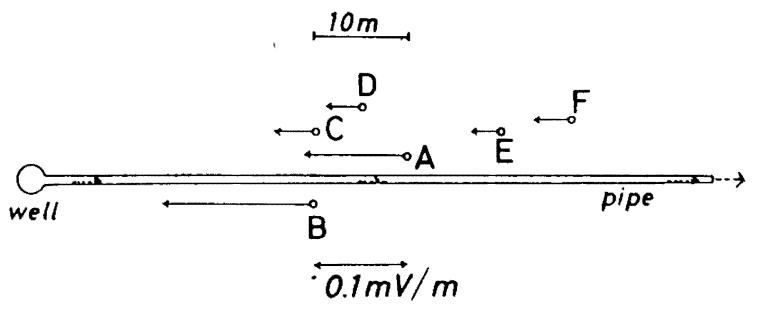

图-20排水管(鉄)を流下する食塩水による鼌場

Fig. 20 An electric field caused by movement of saline through a steel drainpipe.

以上の実験をまとめてみると次のようになる。

1) 多数の地下水(鉄パイプにより)を集めた集水 井から、鉄パイプによって排水している地すべり地 において、集水井に食塩水を投入し流下されると、
見掛け上正電荷が流下するような電場を形成する。

2 ) 集水井の排水バイプを食塩水が流下し始好る と、数 $\sec の$ 後、地表面全体の電位が同時に変化す る。また!電導度の大きい食塩水と鉄パイプのため, 緩和時間が小さく、電位変化の回復が速い。

3) したがって、鉄パイブ中を食塩水が流動する 場合は、その流速を電位変化より測定することは困 難である。

4 ）鉄パイプ中を食塩水が流れる場合は、電気二 重層ができることは考えにくいので、発生する電位 は、流動電位とは考えられない。

\section{$\mathrm{V}$ 流動電位法による地下水の流速測定}

流動電位法を適用し、その効果をみるにあたって、 地下水の分布、水理構造、地質構造の詳細が判明し ている場所が好都合である。地すべり地にはこうし た条件をそなえた所が多い。

1.八木地すべり地における測定

兵庫県養父郡八鹿町八木の地すべり地の末端部を 選んだ。この地すべりは、八木川左岸の山の斜面で、 面積は幅 $80 \mathrm{~m}$ 、長さ $100 \mathrm{~m}$ の小規模なもので、その 末端部は平らな畠となり、畠の端には涌水による池 がある。その断面を図-21(a)に、平面を(b)に示し た。それらに電極配置と推定地下水流脈(点線)を示 してある。地下水流脈については、竹内(1983)の詳 紏な調査結果によった。

実験は、井戸(ボーリング孔、ケーシングは塩ビ管、 直径 $5 \mathrm{~cm}$ 、水温 $14.6^{\circ} \mathrm{C}$ 、気温 $19.7^{\circ} \mathrm{C}$ 、水比抵抗 91 $\Omega \cdot m)$ 一食塩 $1.5 \mathrm{~kg}$ を水 $3 \ell$ に溶かして投入し、 電位の時間的変化を測定した。A 電極(図-21の 1 , 2 は、それぞれ正、負電極を示す。以下同じ)と $\mathrm{B}$ 電極による測定記録を図-22に、それらの電極配置 と直角の配置 C 電極による測定記録を図-23に示す (図-22、23は第 2 回測定)。

図一22における A 電極によるAの電位変化は、 


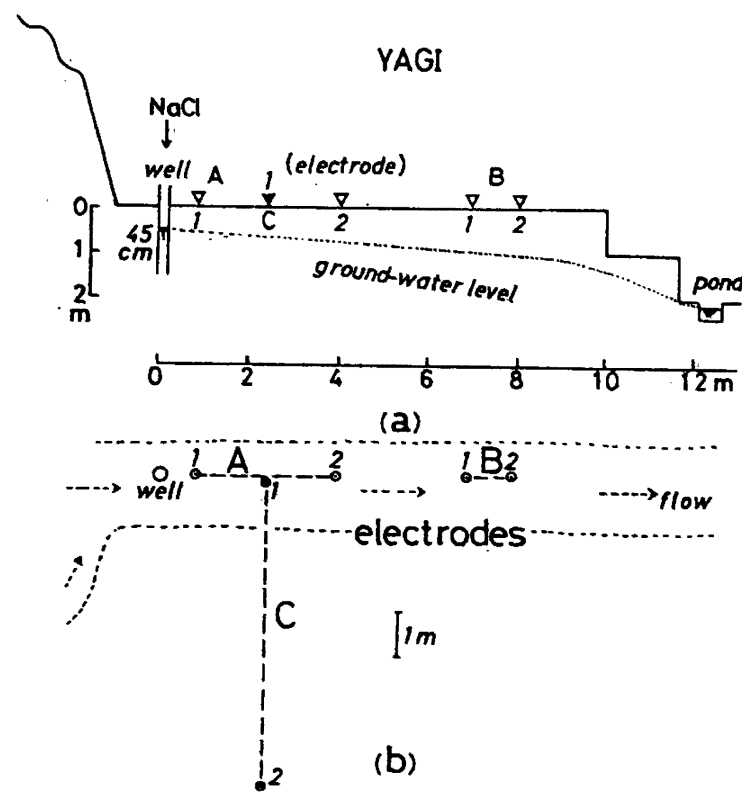

図-21八木地すべり地における電極配置（(a)：断面図， (b) : 平面図)

Fig. 21 Location of the electrodes on ground surface at Yagi landslide area. (a): cross section and (b): plan.

食堨水投入 $(S)$ 後、1.3min後極小值 (矢印 1 ) に達し、 $37.2 \mathrm{~min}$ 後に極大值 (矢印 2 ) となった。極小值は $\mathrm{A}$ 電極の 1 の電極の下(最短距離)に食塩水が到着した ことを示し、極大值は 2 の電極の下に食塩水が到着 したことを示すものと考えられる。図-23における $\mathrm{C}$ 電極では、電位変化における極小値(矢印 1 ) は、 食塩水投入 $(\mathrm{S})$ 後 $19.9 \mathrm{~min}$ である。図 -22 の B 電極 の変化は小さい(Sより最も遠い地点にある)ので、 その極值の時間はやや正確さを欠くが、他の測定(第 1 回)と合わせてみると、極小值(矢卵 1 ) までは49. $4 \mathrm{~min}$ 、極大値までは $58.4 \mathrm{~min}$ (図にはなし、第 1 回 の記録による)であった。以上の結果と、各極値の 電位の大きさ(食塩水投入時の電位を基準として)と を表- 1 に示す。電極などの記号は図-21に示したも のと同じである。

表- 1 において、流速の太きな地点として食塩水 投入孔より $0.85 \mathrm{~m}$ までの S-A 1 の $1.09 \mathrm{~cm} / \mathrm{sec}$ が ある。これは、食塩水 $3 \ell$ 投入によって、一時的
表-1 流動雪位の变化より計萛された流速と電位の極值

Table 1. The flow rate calculated from the variation of streaming potential and the extreme value of electric potential.

(a)

\begin{tabular}{|c|c|c|c|c|}
\hline & 区 間 & 距離(m) & Sより橾値までの时間(min) & 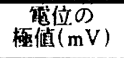 \\
\hline$(1)$ & $\mathrm{S}-\mathrm{Al}$ & 0.85 & 1.3 & $\begin{array}{l}(-) 3.9 \\
(-1.9)\end{array}$ \\
\hline ( 2 ) & $\mathrm{S}-\mathrm{Cl}$ & 2. 35 & 19.9 & $\left\{\begin{array}{l}-14.2 \\
-2.5)\end{array}\right.$ \\
\hline ( 3 ) & $\mathrm{S}-\mathrm{A} 2$ & 3.85 & 37.2 & $(+) 0.9$ \\
\hline (4) & $S-B 1$ & 6.85 & $\begin{array}{r}49.4 \\
(50.4)\end{array}$ & $\left(\begin{array}{l}-0.38 \\
(-0.23)\end{array}\right.$ \\
\hline$(5)$ & $S-B 2$ & 7.85 & (58.4) & $(-0.23)$ \\
\hline
\end{tabular}

第 2 回測定。（）は第 1 回測定

(b)

\begin{tabular}{|c|c|c|c|}
\hline 区 間 & 距雄 $(\mathrm{m})$ & 所要時間 $(\mathrm{min})$ & 流速 $(\mathrm{cm} / \mathrm{sec})$ \\
\hline $\mathrm{S}-\mathrm{A} 1$ & 0.85 & $(1)=1.3$ & 1.09 \\
\hline $\mathrm{A} 1-\mathrm{C} 1$ & 1.50 & $(2)-(1)=18.6$ & 0.13 \\
\hline $\mathrm{C} 1-\mathrm{A} 2$ & 1.50 & $(3)-(2)=17.3$ & 0.14 \\
\hline $\mathrm{A} 2-\mathrm{B} 1$ & 3.00 & $(4)-(3)=13.2$ & 0.38 \\
\hline $\mathrm{B} 1-\mathrm{B} 2$ & 1.00 & $(5)-(4)=9.0$ & 0.19 \\
\hline $\mathrm{A} 1-\mathrm{A} 2$ & 3.00 & $(3)-(1)=35.9$ & 0.14 \\
\hline \hline $\mathrm{A} 1-\mathrm{B} 2$ & 7.00 & $(5)-(1)=57.1$ & 0.20 \\
\hline
\end{tabular}

に水位(水圧)が上昇したため、流速が大きくなった ことによるものであろう。食塩水の投入時には、地 上塩ビ管(孔、図-21参照)から溢れることもなく、 また、投入所要時間も数 sec 以内であった。この孔 付近の地下は、かなり透水性がよいと思われる。次 に、A $2-\mathrm{B} 1$ の $3 \mathrm{~m}$ 間の流速が0. $38 \mathrm{~cm} / \mathrm{sec}$ であ り、その前後より $2 \sim 3$ 倍大きい。この理由はわか らない。あるいは、地すべり地の末端部であるので、 転石や粘土などによって、地下水流脈がくびれてい るのかもしれない。B 1 -B 2 の $1 \mathrm{~m}$ 間では $0.19 \mathrm{~cm}$ / secであるが、電極間隔が $1 \mathrm{~m}$ と短く、感度不足 のため、読取り精度は良くない。A 1-C 1、C 1 -A 2、A 1 -A 2 の流速は0.13〜0.14cm/ $\mathrm{sec}$ で ある、また、A 1 点から B 2 点までの $7 \mathrm{~m}$ 間の流速

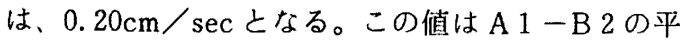
均流速である。この值を除いた表-1の(b)の流速 


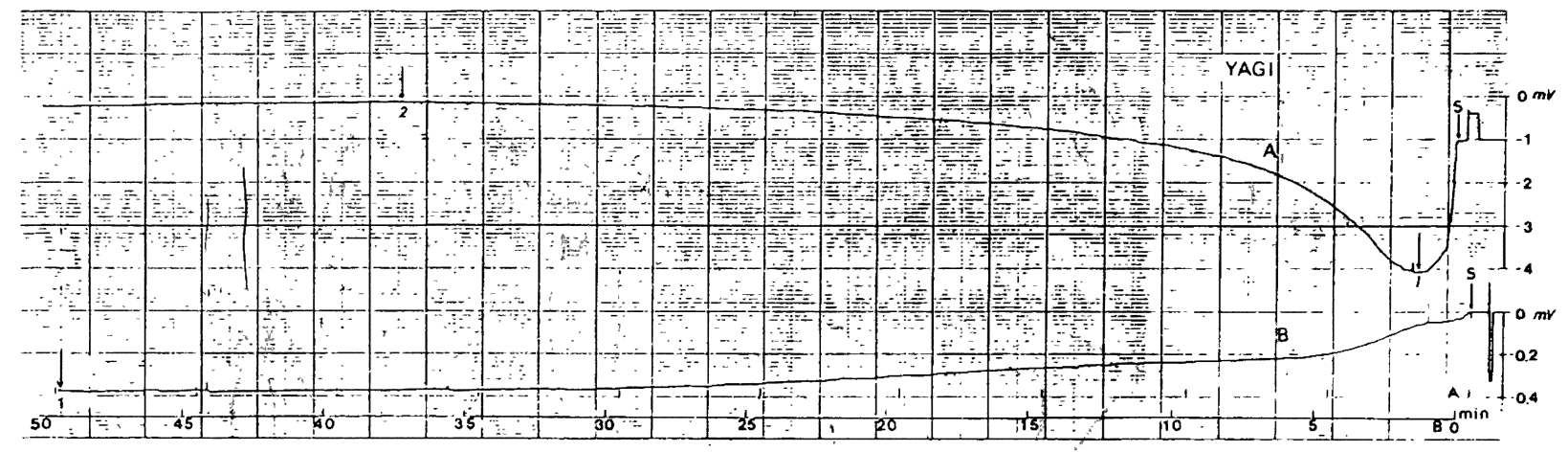

図-22 地下水中に投入した食塩水の移動による流動電位の变化 ( $\mathrm{S}$ ：食塩水投入，1，2：電位変化の極値)

Fig. 22 Temporal variation of streaming potential caused by movement of saline solution injected into underground water. $\mathrm{S}$ indicates injection of saline solution into underground water, and 1 and 2 are the extreme values of electric potential.

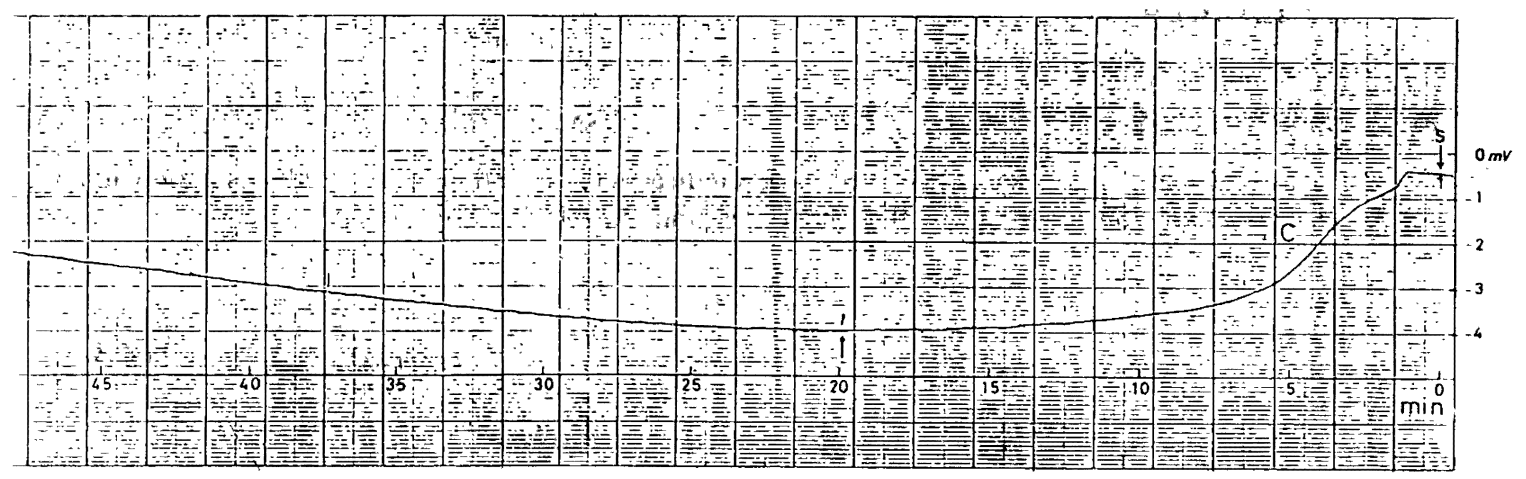

図-23 地下水中に投入した食塩水の移動による流動電位の変化 ( $\mathrm{S}:$ 食塩水投入，1：電位変化の極値)

Fig. 23 Temporal variation of streaming potential caused by movement of saline injected into underground water. $\mathrm{S}$ indicates injection of saline solution into underground water, and 1 is the extreme value of electric potential.

は、部分的な流速(瞬間流速)である。

食塭水投入後、池(図-21の pond)の水の電導度計 による測定から得られた流速は $12 \mathrm{~m} / 131.5 \mathrm{~min} 、 0$. $15 \mathrm{~cm} / \mathrm{sec}$ である。”この值は、電導度が最大となっ た時間から算出したが、水量の多い池での測定では、 最大值をとる時間より以前に食塩水塊が到着してい ることが考えられる(到着後、食塩水は拡散して電 導度計に達するのであろうから)ので、 $0.15 \mathrm{~cm} /$ sec より大きな流速であろう。塩分変化を示し始め た時間からは、 $0.19 \mathrm{~cm} / \mathrm{sec}$ と算出できる。これら
のことを考虑すると： A 1 -B 2 間の流速が $0.20 \mathrm{~cm}$ ／secとなるのは妥当な值であろう。

食塩水投入に先立って、水のみ $3 \ell$ を 2 回投入 してみた。図-24にみられるように、投入後 $47 \mathrm{sec}$ 経て、0.03 0.05mV の電位変化が生じている。水 のみの投入で、遅れをもって電位変化が生じるのは、 明らかに流動電位である。投入孔が径 $5 \mathrm{~cm}$ である ので、加えた圧力は $0.15 \mathrm{~kg} / \mathrm{cm}^{2}$ 程度である。電位 変化の向きは、食塩水投入による向きと逆である。 図-2のモデルの妥当性を示すものといえよう。 


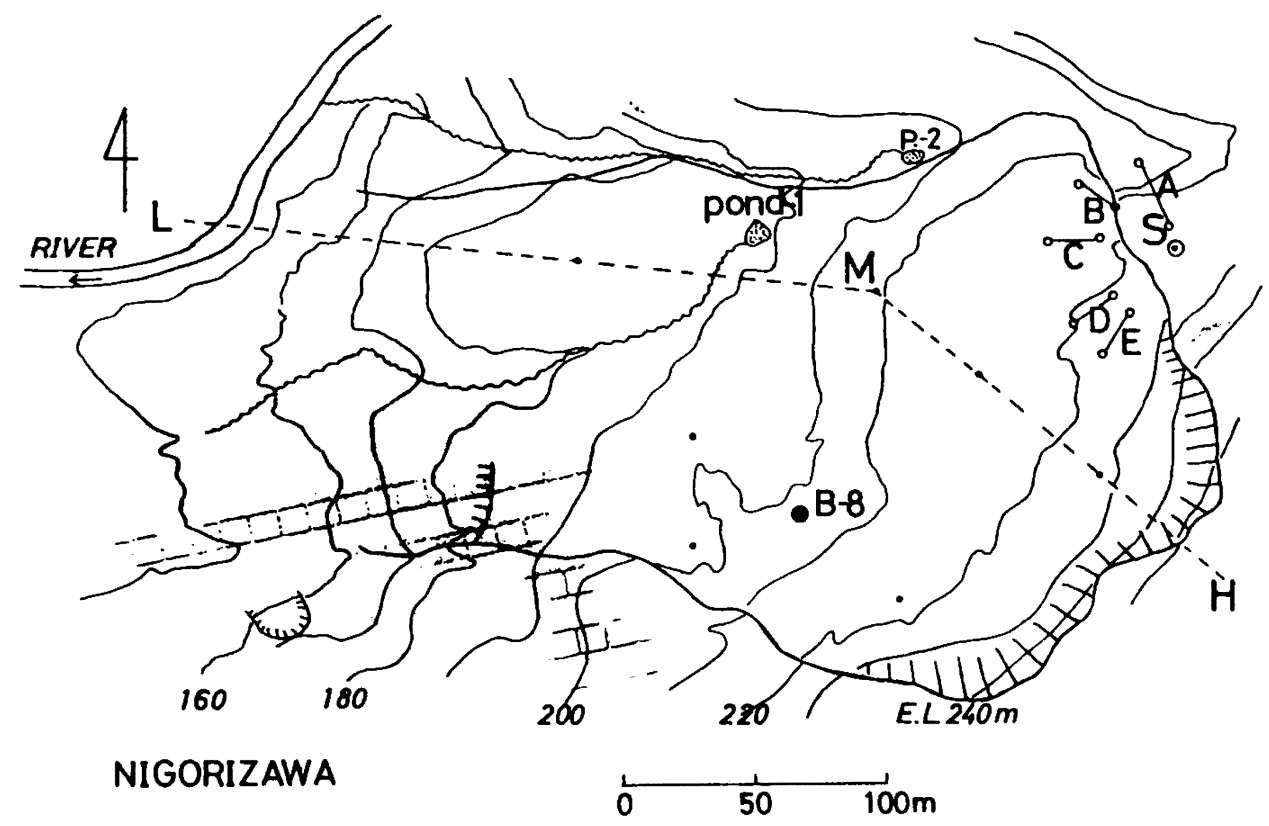

図-25 河沢地すべり地の地形 (S：食塩投入地点; A, B, C, D, E：電極, 黒○と・: 調査孔)

Fig. 25 Topographic map of Nigorizawa landslide area. S indicates the injection point of saline solution and A, B, $\mathrm{C}, \mathrm{D}$, and $\mathrm{E}$ are the locations of the electrodes and the black spots are the borehole.

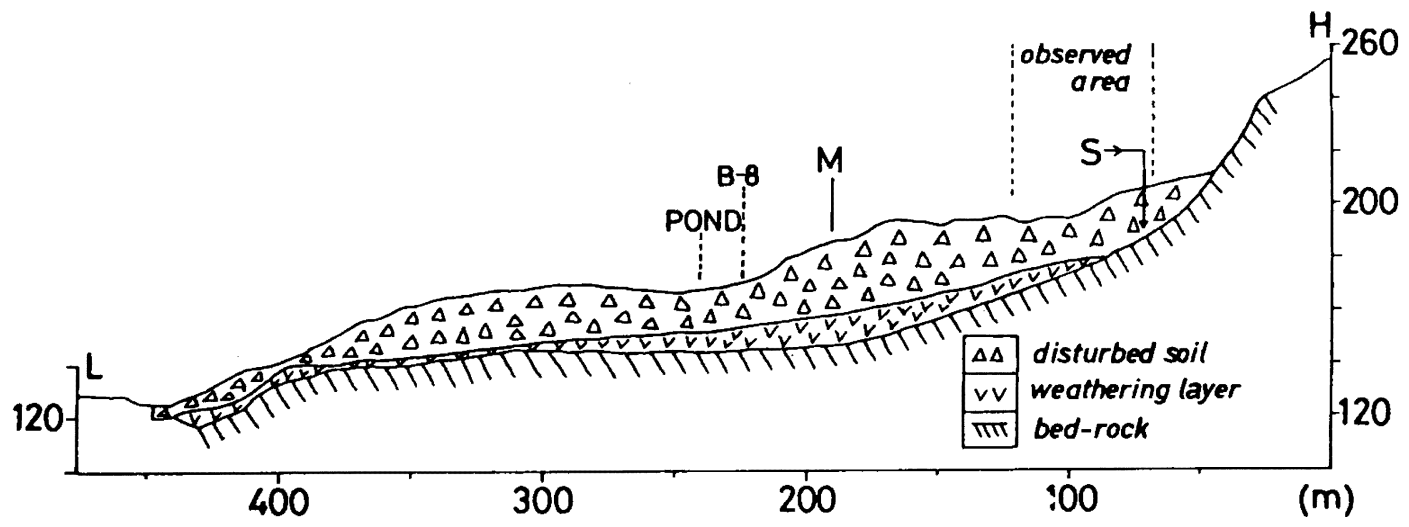

图-26西沢地すべり地の地貫断面図 (HML は図-28(a)の HML と同じ地点)

Fig. 26 Geological cross section along H, M and L in Fig. 28 (a) at Nigorizawa landslide area.

ある。ただし $\mathrm{A}$ 電極のみは、 $\mathrm{S}$ 孔り $5 \mathrm{~m}$ に設置 した。得られだ゙ジタル・プリントの数値をプロッ トした記録を図-28に示す。

図-28の最初の電位変化における極値の大きさと 時刻とより、地下水流動の流速と流量を見積った。
図の S(食塩投入時刻)と A 1、B 1、C 1、D 1、E 1 の時刻差と各電極点までの距離から A、B、C、 D、E 方向（図-27）の流速を求めると、それぞれ、 $0.012,0.060,0.062,0.057,0.054$ (単位はすぺてcm／ $\mathrm{sec})$ となった。これらを見やすく表現するために、 


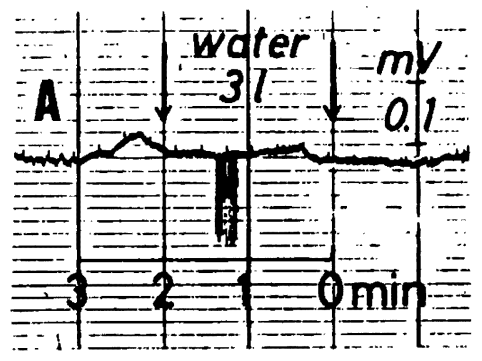

図-24地下水中に投入した水によって発生した流韧電位 (矢印：水投入時刻)

Fig. 24 Streaming potential caused by dropping a water mass into underground water. Arrow indicates the dropping time.

以上の結果をまとめると次のようになる。

1 ) 表- 1 の結果は、第 2 回目の食塩水（食塩 $1.5 \mathrm{~kg}$ 、水 $3 \ell)$ 投入による測定結果である。第 1 回 目は食塩 $500 \mathrm{~g}$ 、水 $3 \ell$ の食塩水を投入したが、表一 1 において見られるように、同じ点における電位の 比は、第 2 回は第 1 回の2.1〜1.7(倍)であるが、食 塩濃度比は3.0(倍)である。図-6のように比例しな いのは、第 1 回の投入食塩が残留していることによ るものであろう。短時間に数回食塩水を投入すると きは、その濃度を次第に増大させてやる必要がある。

2 ) 電極配置は、C 電極のように基準電極を充 分に遠くとるか、 $\mathrm{A}$ 電極のように地下水流脈に平 行である場合は、電極間隔 $(3 \mathrm{~m})$ は地下水面までの 深さ $(1 \mathrm{~m}$ 以下、図-21)の数倍とる必要がある。B 電極は、電極間隔が $1 \mathrm{~m}$ のため、図-22の記録に見 られるように、電位変化における極値の判別が困難 となる。

3 ）流速のベクトルを求める実験は、これからで あるが、その大きさを決定するには、電位変化の絶 対値の精度をあげ、電場の大きさを知る必要がある。 そのためには、電極配置の工夫とともに、電極と土 の接触抵抗を小さくする必要がある。また、数日間 にわたる測定では、電極を $50 \mathrm{~cm}$ 以下に埋設して 地温変化による影響を避けなければならない。
4 ）食塩水投入孔に水のみ投入したときの電位変 化は、食塩水投入による電位変化とその向きが逆で あることは、図-2のモデルの妥当性を示すものと いえよう。水の投入によって水圧が増大し、図-2 の地下水の境界面の正電荷の流動が増加する、すな わち正電荷密度が増加し、それに応じて負電荷が増 加し、一時的に電位が増大することになる。

降雨や気生低下などによる地下水位の変動、荷重 による水圧の增減、地すべり土塊の移動による水圧 の増減などが、短時間に大きく作用するとき、図 -24と同様な現象が観察されるはずである(竹内ら、 1981)。また、不明な原因によって発生し、移動す るという地下水波(酒井、1965)の解明にも、電位変 化を利用できる可能性がある。

\section{2. 濁沢地すべり地における測定}

新潟県長岡市大字濁沢字榎地内の濁沢地すべり は、1980年12月30日正午頃、大規模地すべりが発生 した。長さ $400 \mathrm{~m}$ 、幅 $300 \mathrm{~m}$ 、面積約 $9 \mathrm{ha}$ 、移動土量 90 万 $\mathrm{m}^{3}$ という規模である(新潟県砂防課、1981)。 ここにおいて地下水流速の測定を、従来の方法の食 塩トレーサ法と流動電位法とを併用した実験を行っ た。実験の概要は発表(伊藤ら、1981) されているが、 その後、地すべり地の地質構造の謂查結果が得られ たので詳述する。

電極は鉛電極、地下水電導度測定は改良テス夕を 用い、記録計は長期間、多成分を必要とするので、 測定点数 24 点、測定籍囲 $(-) 10 \sim(+) 50 \mathrm{mV}$ 、分解 能 $10 \mu \mathrm{V}$ 、測定間隔 5 分、デジタル・ブリントの方 式を使用した。

電極配置と投入ボーリング孔、地形および地質断 面図を図-25、26に示した。図のS 点のボーリング 孔に食塩水を多量に投入した。電極配置の詳細は、 図-27に示した。投入孔(S)を囲む25m の円周上の うち、地形的にみて、地下水流動の可能性のある地 点に電極 1 (正極)を、 $40 \mathrm{~m}$ の円周上に電極 2 (負栖) を配置した。したがって、電極対の間隔は15mで 


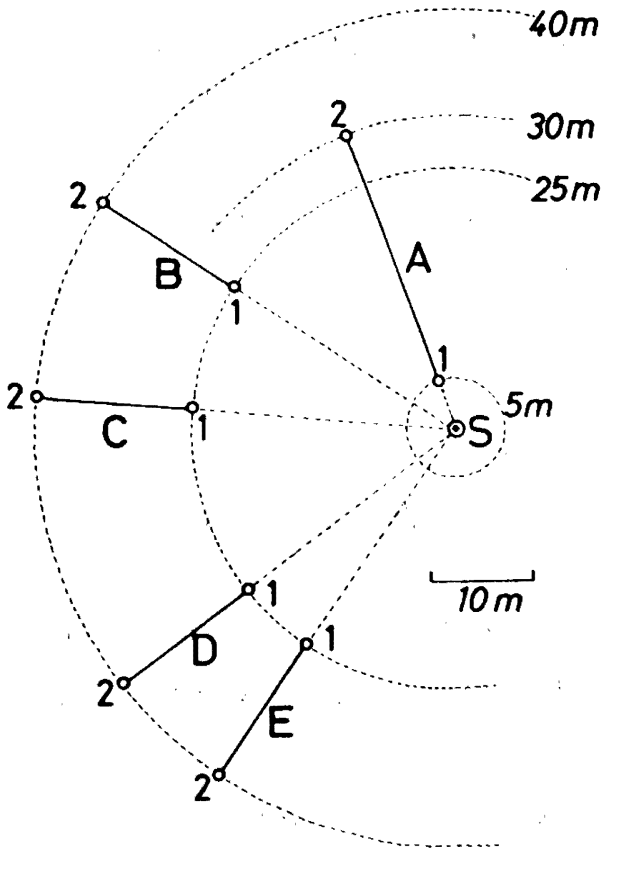

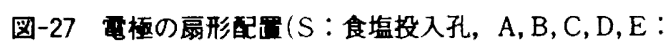
電極)

Fig. 27 An arrangement of the electrodes in a sector. $\mathrm{S}$ indicates saline-solution-injected borehole and $\mathrm{A}, \mathrm{B}, \mathrm{C}, \mathrm{D}$, and $\mathrm{E}$ are the location of the electrodes.
S 点より出発した地下水が 5 時間、20時間後にそれ ぞれどの地点に到着するかを示したのが図-29であ る。これらより地下水は、図一25における東部から 斜面を川方向へ平均 $0.058 \mathrm{~cm} / \mathrm{sec}$ にて流下してい ることがわがっだ。

地下水の流速は判明したが、流量についても検討 してみる。B、C、D、E方向の流速は、はぼ同じ であるが、図-28の極值における電位変化の大きさ はかなり差がある。これらの違いが、地下水流脈の 太さ、食塩水による電荷変化の地中における面積の 大きさによるものとすると、電位変化の大きさは、 流量の大きさに比例すると考えられる。電位変化は A、B、C、D、Eにおいて、それぞれ2.9, 2.1，1.1. $6.3,15.8$ (単位 $\mathrm{mV}$, 絶対值のみ考える)である。 この割合をわかりやすく表現したものが、网-29の 斑点模様の図形である。これが、流量の大小を表す ものとすると、地下水の主流は、図-25の南西方向 に流動していることになる。

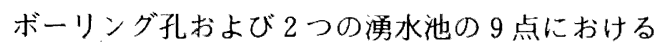
改良テスタによる食塩水の測定において、明瞭な電 導度変化の極大をみたものは、B -8 と POND-

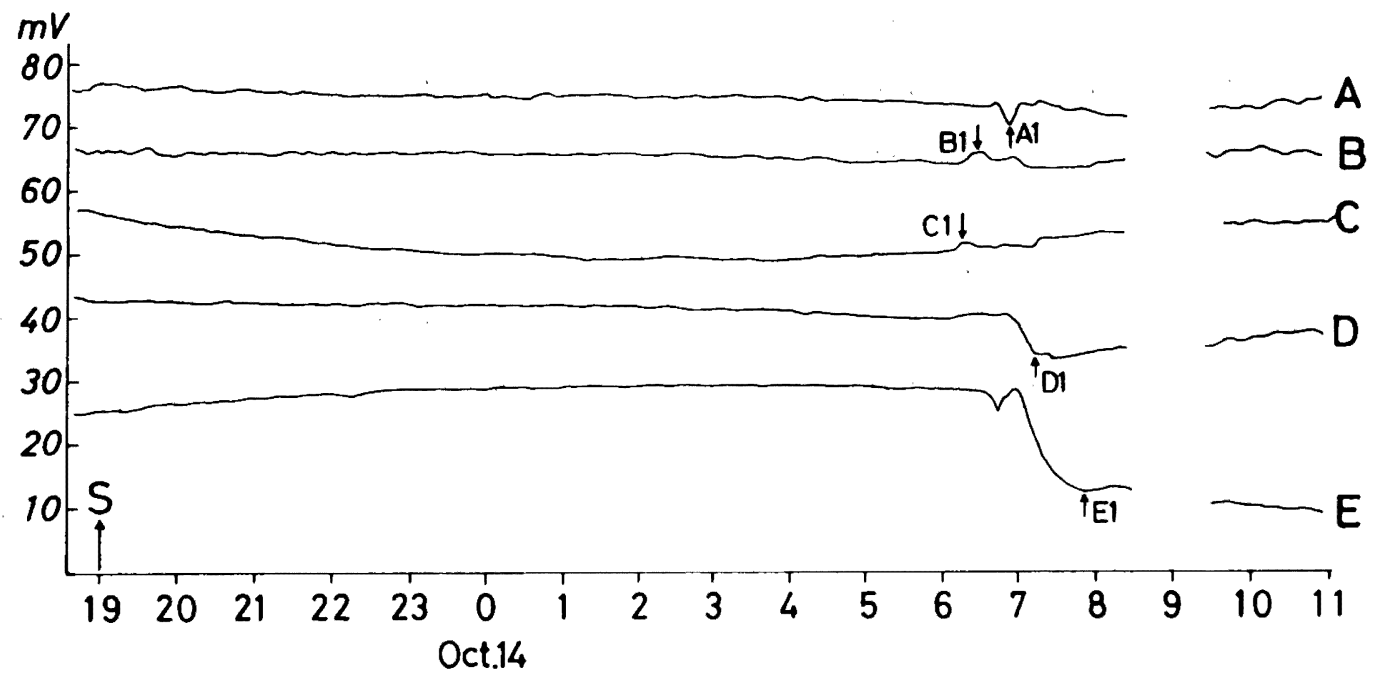

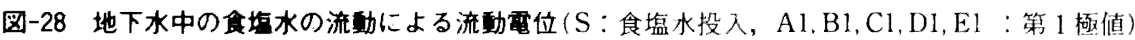

Fig. 28 Streaming potential caused by movement of saline solution injected into underground water. $\mathrm{S}$ indicates the injection of saline solution and $\mathrm{Al}, \mathrm{B} 1, \mathrm{C} 1, \mathrm{D} 1$ and $\mathrm{E} 1$ are the first extreme values of electric potential. 


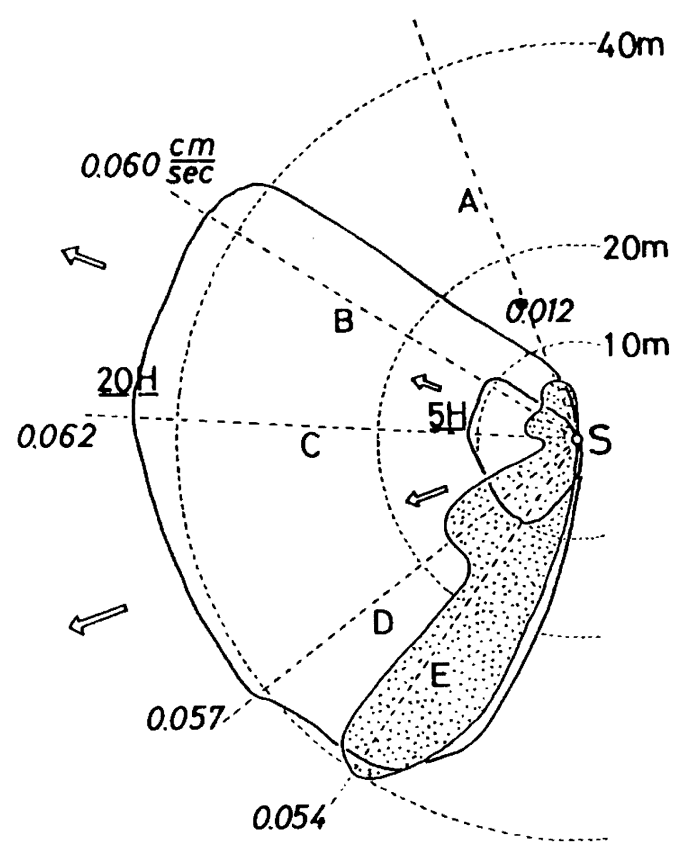

図-29流速分布と流至分布(S：食堨水投入点, $5 \mathrm{H}, 20 \mathrm{H}$ : 5 時間, 20時間後のそれそれの地下水流動節囲, 計算值，点図形：流量分布，電位の極值の比よ り計算された流量)

Fig. 29 Distributions of the flow rate and the flux of underground water. $S$ indicates the injection of saline solution into underground water, $5 \mathrm{H}$ and $20 \mathrm{H}$ are calculated flowing ranges of underground water after 5 and 20 . hours, respectively, and the spotted area shows distribution of flux (relative value expressed by the ratio of the extreme values of electric potential).

1 のみで、流速はそれぞれ、0.12，0.10( $\mathrm{cm} / \mathrm{sec})$ であった。この流速は、流動電位法による流速 $0.058 \mathrm{~cm} / \mathrm{sec}$ の約 2 倍となっている。その理由は、 図-26にみられるように、流動電位法による観測区 域よりも、Bー8、POND-1 近くになって地形の 勾配が急になることによるものと思われる。特に地 質断面図にみられる、透水性の高い第 2 層の風化層 が、流動電位観測域に欠けている、あるい薄いこと によって、斜面上部の地下水流速が小さく、中央部 で大きくなることによるものと思われる。

以上の結果をまとめてみると次のようになる。
1) 電極配置を食塩投入孔を中心として扇形に展 開する方法は、測定結果の解析を容易にする。電極 対の間隔を各対とも等しくし、間隔の大きさを予想 される地下水面までの深さより大きくとることは有 効である。

2 ) 電位計の分解能は0. $1 \mathrm{mV}$ 以上あればよい。 電位変化における極値の正負の問題は今後の課題で ある。

3）食塩トレーサ法との比較においては、地形、 地質構造などを参考にして行わなければならない。

4 ）電位変化の絶対値の比較より、地下水流量、 地下水流脈の大きさの見積りができる見込みがあ る。

VIあとがき

地下水に食塩を投入し、その下流における流動電 位の時間的変化により地下水流速、流量を決定する 流動電位法を確立するために、種々な野外実験を行 い、今後多くの実験を進めるつもりである。

実験にあたり、㗊和地下建設株式会社、川崎地質株式会 社からの便宜に対して深謝する。また、関東学院大学工学 部の山本隆氏ならびに多くの学生より協力を頂いたことを 感謝する。また、防衛大学校の関岡満教授より多く助言を 頂いたことに対して御礼を申し上げる。

\section{参考文献}

伊藤芳朗・斎䓦夫(1973)：温泉涌出に伴う自然雪位の变 動について (I)(日本温泉科学会第26回大会演旨). 温泉 科学, 24, 118 119.

伊藤芳朗・斎藤煇夫・南雲政博(1978)：銭川間欠泉に伴う 流動電位 (I ). 地熱, 15, 19２7.

伊藤芳朗・斎藤輝夫・市川浩・竹内篤婎・熊谷忍・安䖽伐 一・南雲政博 (1981)：流動電位法を用いた地下水の追 跡. 地すべり学会、第20回研究発表会.

橾藤源助・松尾日出夫 (1959)：岩石の流動電位について。 物理探鉱, $12-3,28 \sim 32$.

北原文雄・渡辺昌編(1972)：r界面電気現象」共立出版, 102 115.

酒井軍治郎(1965)：「地下水学」朝會害店, $224 \& 401$.

静電気学会(1981)：「觧電気ハンドブック」オーム社, 
$105 \sim 107$.

竹内篤雄・伊藤芳朗(1981)：地すべり地における自然電位 の長期測定結果について(地すへり発生予知の手段とし て利用するための基礎的検討). 地すべり学会、第20回 研究発表会.

竹内䉆雄 (1983)：「地すべり 地温測定による地下水調査 法」吉井書店, 産業図書, $196 \mathrm{p}$.
新潟県砂防課 (1981)：濁沢地すべり(パンフレット).

Modi, H. J. and D. W. Fuerstenau (1957) : Streaming potential studies on corundum in aqueous solutions of inorganic electrolytes. J. Phys. Chem. , 61, 640 642.

(受付：1984年 5 月10日、受理：1984年 8 月 4 日) 